\title{
Tournament Incentives and Acquisition Performance
}

\section{Iftekhar Hasan}

Fordham University, University of Sydney, and Bank of Finland, ihasan@fordham.edu

\section{Marco Navone}

University of Technology Sydney, marco.navone@uts.edu.au

\section{Thomas Y. To}

University of Sydney, thomas.to@sydney.edu.au

\section{Eliza Wu}

University of Sydney, eliza.wu@sydney.edu.au

\begin{abstract}
This paper examines the impact of promotion-based tournament incentives on corporate acquisition performance. Measuring tournament incentives as the compensation ratio between the CEO and other senior executives, we show that acquirers with greater tournament incentives experience lower announcement returns. Further analysis shows that the negative effect is driven by the risk-seeking behavior of senior executives induced by tournament incentives. Our results are robust to alternative identification strategies. Our evidence highlights that senior executives, in addition to the CEO, play an influential role in acquisition decisions. (JEL G30, G34, G41, J31, J33, J62)
\end{abstract}

Received: November 5, 2018; editorial decision January 6, 2020 by Editor Isil Erel.

\section{Introduction}

Corporate acquisitions are one of the largest forms of corporate investment. As such, one would expect managers to exert a lot of effort into selecting acquisition targets that can create shareholder value. Paradoxically, the literature has found that this is often not the case

We thank two anonymous reviewers; Isil Erel (the editor), Sumit Agarwal, Si Cheng, Gonul Colak, Fangjian Fu, Gilberto Loureiro, Ronald Masulis, Thomas Noe, Buhui Qiu, David Reeb, Xuan Tian, Anh Tran, Nam Tran, and David Yermack; and conference participants at the 2017 SFS Cavalcade Asia-Pacific, 2017 FIRCG Conference at University of Melbourne, and 2018 Executive Compensation Conference at Erasmus University for helpful comments and discussions. All errors remain our own. Send correspondence to Eliza Wu, Codrington Street, Darlington, NSW 2008, Australia; telephone: +61-2-86274626. E-mail: eliza.wu@sydney.edu.au. (http://creativecommons.org/licenses/by/4.0/), which permits unrestricted reuse, distribution, and reproduction in any medium, provided the original work is properly cited. 
with corporate managers perpetually embroiled in the destruction of shareholder wealth via poor acquisition decisions (Andrade, Mitchell, and Stafford 2001; Moeller, Schlingermannn, and Stulz 2005; Hackbarth and Morellec 2008). Some authors show that the decision to make value destroying acquisitions could be due to the empire building motive of the chief executive officer (CEO) (Jensen 1986; Lang, Stulz, and Walkling 1991; Masulis, Wang, and Xie 2007; Harford, HumpheryJenner, and Powell 2012), whereas others have pointed out that managers who receive little equity-based compensation have little incentive to make good acquisitions (Lewellen and Loderer 1985; Datta, Iskandar-Datta, and Raman 2001). However, there is relatively scant evidence on how incentives of senior executives other than the CEO can play an incremental role in affecting acquisition performance.

The prior literature shows that senior executives are heavily involved in acquisition decisions. For example, in more than 80 interviews conducted by Graebner (2009), they show that vice presidents in acquiring firms are heavily involved in making acquisition decisions, whereas Greene and Smith (2018) document that CEOs are likely to delegate their authority to other senior executives in acquisition decisions. The prior literature also show that senior executives of bidding companies tend to receive pay increases after completing an acquisition. Specifically, Firth (1991) finds that senior executives are likely to receive a pay increase regardless of the performance of the acquisition, whereas Coakley and Iliopoulou (2006) show that the pay increase is proportional to deal size. Yet, to the best of our knowledge, prior literature has not directly examined how incentives of senior executives other than that for the CEO can directly affect acquisition performance, and thereby affecting shareholder wealth. This is surprising, because senior executives are heavily involved in acquisition decisions. In this paper, we aim to fill this gap in the literature by examining the effect of tournament incentives of senior executives (created by an observable pay differential between the CEO and other senior executives, whom we refer to collectively as VicePresidents (VPs) hereafter) on corporate acquisition performance.

Over the past decade, CEO pay has received much attention from the media. Due to the skewed corporate pay structure, the advancement of senior executives in a corporate hierarchy is often viewed as a tournament in which individuals compete with one another for the CEO position. The compensation gap between workers of various ranks as a feature of tournament incentives was first proposed by Lazear and Rosen (1981). They argue that the large compensation packages received by executives are likely to induce all lower-ranked employees in the firm to compete and work harder to increase their chances of securing a promotion. In the same vein, Bognanno (2001) focuses on CEO promotion tournaments and uses the compensation gap between the CEO and other 
senior executives as the measure of tournament incentives. Since virtually every major corporate decision requires the combined efforts of the senior executive team, studies have found that tournament incentives are associated with improved innovative efficiency (Jia, Tian, and Zhang 2017; Shen and Zhang 2018) and better firm performance (Kale, Reis, and Venkateswaran 2009; Chen, Ezzamel, and Cai 2011; Burns, Minnick, and Starks 2017; Hjertstrand and Swfford 2019).

Due to these findings, our primary hypothesis which we label the "effort inducement hypothesis," predicts that firms with greater tournament incentives should make better acquisitions as the senior executives (VPs) in these firms would put more effort into assisting the CEO to identify which acquisitions would benefit the company the most in order to try and win the tournament prize (the pay gap). Anecdotal evidence suggests that the senior executive team put a lot effort in acquisition decisions. For example, in an interview with Google's corporate development VP Don Harrison, Harrison said, "my team, the deal sponsors, and Google's senior executives sit around the room to really decide whether or not this (the acquisition) is something we should do" (D'Onfro 2015).

On the other hand, several studies have shown that higher tournament incentives also encourage greater risk-taking by senior executives. Goel and Thakor (2008) theoretically model the relation between tournament incentives and corporate risk-taking. In their model, they document that if every senior executive chooses the same level of risk as his competitors in the CEO promotion tournament, they will all have the same output at the end of the period given the risk-return relationship. The probability of getting promoted for all of the senior executives would then also be the same. Therefore, each executive can increase his own probability of promotion by taking on or supporting the CEO and board members in pursuing riskier and larger projects as these projects can yield more extreme outcomes. Hvide (2002) and Glilpatric (2009) show that such risktaking is often pursued at the expense of efficiency as they demonstrate that the option-like payoff structure of promotion tournaments generate perverse incentives for executives to engage in "excessive" risk-taking (invest in more highly risky projects that have a lower mean output), while Haß, Müller, and Vergauwe (2015) show that greater tournament incentives lead to a higher likelihood of corporate fraud due to executives' excessive risk-taking behavior.

Based on these established findings on the effect of tournament incentives on managers' risk-seeking behavior, we expect that corporate senior executives would rationally support the CEO and board members in making more acquisitions. In particular, the VPs are likely to advocate and support those extremely large and risky acquisitions when they are given the task of evaluating potential acquisition targets, because these 
deals can yield more extreme outcomes which increase their own chances of winning the promotion tournament. The failure to support these deals may push an executive down the rank in the tournament if one of these acquisitions eventually achieves a big success for the company. More importantly, senior executives are unlikely to receive any severe punishment if the acquisition fails as the CEO has the final say on acquisitions and is likely to be held publicly accountable, especially for these large acquisitions where the CEO is likely to face extreme pressure from the media once the acquisition fails (Lehn and Zhao 2006; Fee et al. 2018). Moreover, objecting to these large and risky deals would unlikely benefit senior executives even if these deals fail as they are typically aligned with the longer-term strategic plans set for the company and backed by the board of directors, and the board ultimately decides who the next CEO would be. Hence, our alternative risk-seeking hypothesis predicts that firms with greater tournament incentives are more likely to make more overly risky acquisitions as the senior executives in these firms are in theory more motivated to support the pursuit of extremely large and risky acquisitions to increase their own chances of securing a promotion.

We test these two competing hypotheses by empirically examining the relation between tournament incentives and acquisition performance using an extensive sample of 8,911 corporate acquisitions from 1994 to 2015. Controlling for performance-based incentives and risk-taking incentives of the $\mathrm{CEO}$, firm, and deal characteristics, together with year and industry fixed effects, our baseline results indicate that tournament incentives created by pay gaps between the CEO and VPs are negatively related to the firm's acquisition performance as measured by cumulative abnormal stock returns around the acquisition announcement.

While our baseline results are more supportive of our risk-seeking hypothesis, a potential concern is that unobservable firm heterogeneity correlated with both a firm's pay gap and acquisition performance may be driving the results (i.e., the omitted variable concern), which makes it difficult to establish causality.

We address the endogeneity concern with two alternative approaches, although we are aware that they can only alleviate, but not completely solve, the endogeneity problem due to the lack of direct exogenous shocks in the executive compensation literature (Adams, Hermalin, and Weisbach 2010; Coles, Lemmon, and Meschke 2012; Edmans, Gabaix, and Jenter 2017). First, we employ an instrumental variable approach where we instrument tournament incentives with the number of VPs and size-adjusted industry average tournament incentives, as prior studies suggest that the tournament prize increases with the number of VPs and the level and structure of managerial compensation varies by firm size and industry. The negative relationship between tournament 
incentives and acquisition performance remains robust to the use of these instruments. Second, we follow Shen and Zhang (2018) and perform regression analysis based on a propensity-score matched sample to control for the systematic differences in firm and deal characteristics between firms with high and low tournament incentives. We find that our results are also robust to this matching procedure.

We rule out that our findings may be driven by an entrenchment hypothesis. This competing hypothesis arises as the pay gap between the $\mathrm{CEO}$ and other senior executives also can be interpreted as CEO entrenchment (Bebchuk, Cremers, and Peyer 2011; Chen, Huang, and Wei 2013), and the prior literature has found that entrenched CEOs make worse acquisitions (Masulis, Wang, and Xie 2007; Harford, Humphery-Jenner, and Powell 2012). To distinguish our tournament hypothesis from the entrenchment hypothesis, we first explicitly control for $\mathrm{CEO}$ entrenchment in all of our regressions. Second, we adopt a twostage regression approach, where in the first stage we decompose the pay gap measure into the part that proxies for CEO entrenchment and the residual part which more likely proxies for tournament incentives and in the second stage we use the residual as our proxy for tournament incentives. We continue to find a negative relationship between tournament incentives and acquisition performance.

We then examine the source of the value destruction. According to our risk-seeking hypothesis, we expect the adverse effect of tournament incentives to be driven by the excessive risk-taking behavior of senior executives induced by tournament incentives. Our empirical evidence indicates three striking results. First, we find that firms with stronger tournament incentives are more likely to conduct corporate acquisitions, and the additional acquisitions are more likely to be value destroying. Second, we discover that the adverse effects of tournament incentives on acquisition performance are stronger for extremely large and highly risky deals, as these deals are more likely to be conducted due to VPs' riskseeking behavior. Third, we show that the negative effect of tournament incentives is strongest in firms which the senior executives are more likely to participate in the tournament, such as in firms that are more likely to hire the next CEO from internal ranks and in firms where certain VPs are significantly behind in the tournament and have the incentives to maximize corporate risk-taking to catch up to the tournament leaders.

To check the robustness of our results, we use alternative constructs to proxy for tournament incentives, include other forms of senior executives' incentives as additional controls in our regressions, and exclude firms with no senior executives other than the CEO on the board. We find that our results continue to hold in each of these robustness checks.

Our paper contributes to two separate strands of literature. First, it contributes new evidence to the extensive literature on agency problems 
in corporate acquisitions. Prior studies have generally found that managers in firms with weaker corporate governance (Masulis, Wang, and Xie 2007; Harford, Humphery-Jenner, and Powell 2012) and those having excessive cash flows (Jensen 1986; Harford 1999) are more likely to make value destroying acquisitions. In contrast, firms that provide managers with a higher level of equity-based compensation (Lewellen, Loderer, and Rosenfeld 1985; Datta, Iskandar-Datta, and Raman 2001) are more likely to make value enhancing acquisitions. However, to the best of our knowledge, no study has examined how the difference in compensation levels between the CEO and other senior executives can lead to agency problems that affect acquisition performance. This is an important research question because almost every corporate acquisition decision requires the combined efforts and agreements of its senior executive team for a successful execution. Our study contributes to the literature by showing that tournament incentives induce senior executives to support overly risky acquisitions that on average destroy shareholder value.

Second, our paper contributes to the growing literature examining the effects of tournament incentives. On the bright side, existing studies find that greater tournament incentives lead to improved innovative efficiency (Jia, Tian, and Zhang 2017; Shen and Zhang 2018) and better firm performance (Kale, Reis, and Venkateswaran 2009; Chen, Ezzamel, and Cai 2011; Burns, Minnick, and Starks 2017). On the dark side, prior research finds that greater tournament incentives can lead to excessive risk-taking (Goel and Thakor 2008) and a higher likelihood of corporate fraud (Haß, Müller, and Vergauwe 2015). By using a large sample of corporate acquisitions, we are able to contribute new evidence on the effects of tournament incentives on corporate acquisition performance and provide an additional perspective in this debate.

\section{Data Sources and Variable Construction}

\subsection{Data sources}

We obtain compensation data for CEO and other senior executives from the Standard and Poor's (S\&P) ExecuComp database. Following Kale, Reis, and Venkateswaran (2009), we classify an executive as a CEO if he is identified as the CEO of a firm in ExecuComp (CEOANN = CEO), and classify all other senior executives as VPs. We also collect numerous CEO related variables from ExecuComp, such as the tenure of the CEO, whether the CEO is also the Chair of the firm, whether the CEO was promoted from within the firm, and the number and value of options held by the CEO. We then obtain board information from RiskMetrics, financial data from Compustat and financial markets data from CRSP for our sample of firms in the ExecuComp database. 
Table 1

Number of acquiring firms and acquisitions by year

\begin{tabular}{lrc} 
Year & Number of acquiring firms & Number of acquisitions \\
\hline 1994 & 161 & 248 \\
1995 & 202 & 296 \\
1996 & 263 & 398 \\
1997 & 276 & 433 \\
1998 & 296 & 480 \\
1999 & 334 & 551 \\
2000 & 300 & 486 \\
2001 & 281 & 435 \\
2002 & 283 & 405 \\
2003 & 311 & 448 \\
2004 & 334 & 489 \\
2005 & 337 & 488 \\
2006 & 312 & 449 \\
2007 & 302 & 470 \\
2008 & 286 & 394 \\
2009 & 237 & 317 \\
2010 & 273 & 370 \\
2011 & 296 & 379 \\
2012 & 310 & 402 \\
2013 & 252 & 331 \\
2014 & 275 & 355 \\
2015 & 222 & 287
\end{tabular}

This table reports the number of firms that made acquisitions and the number of firms that they acquired in each year during our entire sample period.

To examine the effect of tournament incentives on acquisition performance, we collect acquisitions data from the Securities Data Company (SDC) M\&A database from 1994 to 2015 . We require a minimum deal value of $\$ 1$ million and we include only deals where the acquiring firm controls less than $50 \%$ of the target's stocks before the announcement and owns $100 \%$ of the target's stocks after the transaction. After merging across databases, we end up with a final sample of 8,911 acquisitions made by 1,934 acquirers during 1994 to 2015 . Table 1 shows that the number of firms and the number of acquisitions are fairly stable across time.

\subsection{Tournament incentives}

We use two measures to capture a firm's tournament incentives. Following Burns, Minnick, and Starks (2017), we use the ratio between CEO's total compensation package and the mean VP's total compensation package as our main measure of tournament incentive. As a robustness check, we also follow Kini and Williams (2012) and use the pay gap between the CEO and the median VP as our alternative measure of tournament incentives. ${ }^{1}$

1 Following Kini and Williams (2012), we removed 367 observations for which the median VP's pay is higher than the CEO's, as the authors find that in nearly all of these firms the CEO was also the founder of the company and received little or no compensation. For these observations, the calculated tournament incentive measures are likely to be a noisy proxy of firm's tournament incentives. 


\subsection{Executive, firm, and deal characteristics}

We control for CEO alignment and CEO risk taking incentives as they have been shown to affect corporate investment decisions (Bizjak, Brickley, and Coles 1993; Armstrong and Vashishtha 2012; Kumar and Langberg 2014). Guided by the prior work of Kini and Williams (2012), we include as control variables $\ln (C E O$ delta $)$ and $\ln (C E O$ vega $)$. CEO delta is computed as the dollar increase in a CEO's portfolio wealth for a $1 \%$ increase in the firm's stock price, whereas CEO vega is computed as the dollar increase in a CEO's portfolio wealth for a $1 \%$ increase in the standard deviation of the firm's stock volatility. ${ }^{2}$ We also include CEO entrenchment as a control variable, because prior studies document that entrenched CEOs make worse acquisitions (Masulis, Wang, and Xie 2007; Harford, Humphery-Jenner, and Powell 2012). Specifically, we combine multiple CEO entrenchment measures into a broader index of governance quality. The measures we use include the entrenchment index (Bebchuk, Cohen, and Ferrell 2009) CEO/Chair duality (Jensen 1993), whether the CEO is the only insider director (Adams, Almeida, and Ferreira 2005), whether the CEO is highly tenured (Berger, Ofek, and Yermack 1997), and CEO hubris (Roll 1986). To construct the index, we split each of the CEO entrenchment measures into two groups, with higher values indicating higher entrenchment, and cumulate the ranks $(0-1)$. We then divide the cumulated ranks by the number of measures available for the firm-year to obtain the CEO entrenchment index score. ${ }^{3}$ In addition, we also control for CEO turnover, number of VPs and VP acquisition experience.

Following the acquisition literature, we control for a vector of firm and deal characteristics that may affect a firm's acquisition decisions (variable definitions are provided in the appendix). Our firm-level controls include firm size, leverage, Tobin's q, cash flow, governance quality, and stock price runup. Our deal-level controls include relative deal size, method of payment, target public status, cross-industry indicator, cross-border indicator and M\&A wave. Following Jenter and Lewellen (2015), we combine multiple governance measures into a broader index of governance quality. The measures we use include board independence, board size and institutional ownership (Aggarwal et al. 2011; Guo and Masulis 2015). Similar to constructing the CEO entrenchment index, we split each of the governance measures into two groups, with higher values indicating

2 We thank Lalitha Naveen for making the data on CEO delta and CEO vega publicly available. See Coles, Daniel, and Naveen (2006) for the detailed steps involved in the calculations.

3 Combining different measures into a single CEO entrenchment index helps us to control for multiple aspects of CEO entrenchment without sacrificing sample size, because entrenchment index is only available until 2006, and board information is only available from 1996. We also separately examine each of these measures (with the exception of the entrenchment index, as the data are only available until 2006) in Section 3.2. 
better governance, and cumulate the ranks $(0-1)$. We then divide the cumulated ranks by the number of measures available for the firm-year to obtain the governance index score. ${ }^{4}$

\subsection{Summary statistics}

Table 2 shows the summary statistics. We winsorize all continuous variables at the 1st and 99th percentiles. Tournament incentives and executives and firm characteristics are all measured at the fiscal year-end prior to the acquisition announcement. Panel A reports that on average the CEO earns 3.03 times more than the average VP in the firm and has been the CEO of the firm for 7 years. Among the CEOs, $69 \%$ of them were promoted internally and $28 \%$ of them sit on the board as the only insider director. Panel B shows that an average acquirer in our sample has a leverage ratio of $18 \%$ and Tobin's q of 2.17 , which is consistent with the figures reported in prior studies (e.g., Yim 2013; Huang et al. 2014). Panel $\mathrm{C}$ shows that the average 5-day cumulative abnormal (announcement) return for our sample of acquisitions is $0.41 \%$ and the size of the average acquisition is $12 \%$ of acquirer's market capitalization. Among the acquisitions, $43 \%$ are cross-industry deals, $21 \%$ are cross-border deals, and $40 \%$ are funded entirely by cash.

\section{Tournament Incentives and Acquirer Announcement Returns}

\subsection{Baseline results}

To investigate the relation between tournament incentives and acquisition performance, we first examine univariate comparisons of acquisition performance for firms with different levels of tournament incentives. For each year, we split all acquirers in that year into three groups based on their level of tournament incentives. The low-tournament-incentive group consists of the bottom third of all firms, the mediumtournament-incentive group consists of the middle third of the firms, and the high-tournament-incentive group consists of the top third of the firms. We then conduct a univariate analysis to examine the relation between tournament incentives and acquisition performance. Table 3 reports the results. The mean (median) announcement return of the low-tournament-incentive group is $0.59 \%(0.39 \%)$, while the mean (median) announcement return of the high-tournament-incentive group is significantly lower at $0.25 \%(0.12 \%)$. These results indicate that a firm's

4 Similar to our handling of the CEO entrenchment index, combining different measures into a single governance index helps us to control for multiple aspects of firm governance without sacrificing sample size. To be consistent with our CEO entrenchment index, we divide the governance measure at the median rather than at the tercile, as in Jenter and Lewellen (2015). All our results are similar if we divide the governance measure at the tercile rather than at the median. 
Table 2

Summary statistics

\begin{tabular}{|c|c|c|c|c|c|c|}
\hline & $\mathrm{N}$ & Mean & SD & Q1 & Median & Q3 \\
\hline \multicolumn{7}{|c|}{ A. Compensation and executive characteristics } \\
\hline Pay ratio & 8,911 & 3.03 & 1.80 & 1.97 & 2.64 & 3.49 \\
\hline CEO delta & 8,911 & 1.00 & 2.40 & 0.12 & 0.31 & 0.80 \\
\hline CEO vega & 8,911 & 0.18 & 0.32 & 0.02 & 0.07 & 0.19 \\
\hline CEO tenure & 8,650 & 7.02 & 7.21 & 2.00 & 5.00 & 10.00 \\
\hline CEO-chair & 8,911 & 0.62 & 0.49 & 0.00 & 1.00 & 1.00 \\
\hline CEO is only insider director & 6,525 & 0.28 & 0.45 & 0.00 & 0.00 & 1.00 \\
\hline Insider CEO & 4,555 & 0.69 & 0.46 & 0.00 & 1.00 & 1.00 \\
\hline CEO turnover & 8,911 & 0.09 & 0.29 & 0.00 & 0.00 & 0.00 \\
\hline Number of VPs & 8,911 & 4.94 & 1.15 & 4.00 & 5.00 & 6.00 \\
\hline VP acquisition experience & 8,911 & 2.67 & 1.95 & 0.00 & 3.00 & 4.00 \\
\hline VP delta & 8,863 & 0.19 & 0.38 & 0.03 & 0.07 & 0.18 \\
\hline VP vega & 8,906 & 0.05 & 0.08 & 0.01 & 0.02 & 0.05 \\
\hline \multicolumn{7}{|l|}{ B. Firm characteristics } \\
\hline Firm size (\$billions) & 8,911 & 6.68 & 14.68 & 0.53 & 1.47 & 4.82 \\
\hline Leverage & 8,911 & 0.18 & 0.17 & 0.04 & 0.13 & 0.26 \\
\hline Tobin's q & 8,911 & 2.17 & 1.45 & 1.30 & 1.73 & 2.45 \\
\hline Cash flow & 8,911 & 0.14 & 0.08 & 0.09 & 0.14 & 0.19 \\
\hline Independent directors & 6,525 & 0.71 & 0.17 & 0.61 & 0.75 & 0.85 \\
\hline Board size & 6,525 & 9.68 & 2.84 & 8.00 & 9.00 & 11.00 \\
\hline Institutional investors & 8,862 & 0.71 & 0.20 & 0.60 & 0.74 & 0.86 \\
\hline Entrenchment index & 4,711 & 2.16 & 1.29 & 1.00 & 2.00 & 3.00 \\
\hline Stock price runup & 8,911 & -0.02 & 0.41 & -0.25 & -0.02 & 0.20 \\
\hline \multicolumn{7}{|l|}{ C. Deal characteristics } \\
\hline CAR $(\%)$ & 8,911 & 0.41 & 6.05 & -2.44 & 0.24 & 3.26 \\
\hline Relative deal size & 8,911 & 0.12 & 0.22 & 0.01 & 0.04 & 0.12 \\
\hline Cross-industry & 8,911 & 0.43 & 0.49 & 0.00 & 0.00 & 1.00 \\
\hline Cross-border & 8,911 & 0.21 & 0.41 & 0.00 & 0.00 & 0.00 \\
\hline All-cash deal & 8,911 & 0.40 & 0.49 & 0.00 & 0.00 & 1.00 \\
\hline Private target & 8,911 & 0.43 & 0.50 & 0.00 & 0.00 & 1.00 \\
\hline Subsidiary target & 8,911 & 0.36 & 0.48 & 0.00 & 0.00 & 1.00 \\
\hline M\&A wave $(000 s)$ & 8,911 & 0.23 & 0.26 & 0.08 & 0.15 & 0.27 \\
\hline
\end{tabular}

This table reports the summary statistics for variables constructed based on the sample of U.S. public firms from 1994 to 2015. Panel A reports the summary statistics for compensation variables and executive characteristics. Panel B reports the summary statistics for firm characteristics. Panel C reports the summary statistics for deal characteristics. All continuous variables are winsorized at the 1st and 99th percentile levels. Table A1 in the appendix defines all variables.

Table 3

Univariate acquirer announcement return analysis

\begin{tabular}{lcc} 
& \multicolumn{2}{c}{ CAR $(-2,+2)$} \\
\cline { 2 - 3 } Tournament incentive group & Mean & Median \\
\hline Low & 0.59 & 0.39 \\
Medium & 0.38 & 0.23 \\
High & 0.25 & 0.13 \\
Difference (high - low) & $-0.34^{* *}$ & $-0.26^{* *}$ \\
$p$-value & .03 & .02 \\
\hline
\end{tabular}

This table reports and compares the mean and median acquirer announcement returns for different tournament incentive groups. The low tournament incentive group has the bottom tercile of the observations, and the high tournament incentive group has the top tercile of the observations. A $t$-test and a signed-rank test are performed on the differences in acquirer announcement returns between the high tournament incentive group and the low tournament incentive group. ${ }^{*} p<.1 ;{ }^{* *} p<.05 ; * * *<.01$. 
tournament incentives is negatively associated with acquisition performance, which is consistent with our risk-seeking hypothesis.

Next, we examine the relation between tournament incentives and acquisition performance using a multivariate model. Specifically, we estimate the following model:

$$
C A R_{i, t}=\alpha+\beta \text { LnPayRatio }_{i, t-1}+\gamma Z_{i, t-1}+\text { YearFE }+ \text { IndustryFE }+\varepsilon_{i, t},
$$

where $t$ denotes year, $i$ denotes firm, and $j$ denotes industries. The dependent variable, $C A R_{i, t}$, is the 5-day cumulative abnormal returns around the acquisition announcement date. Following Masulis, Wang, and Xie (2007), the abnormal stock returns are calculated by estimating the market model for each acquirer over a 200 day period ending 11 days before the announcement date $(-210,-11)$ with the CRSP value-weighted return as the market index. The tournament incentives measure,

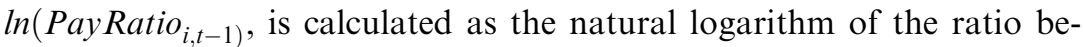
tween CEO's total compensation package and the mean VP's total compensation package in the year before the acquisition. $Z_{i, t-1}$ is a vector of firm, CEO, and deal characteristics that are likely to affect a firm's acquisition performance. YearFE and IndustryFE capture time and industry fixed effects respectively. Because of the large presence of serial acquirers in our sample, the residuals in our regressions may be correlated and hence may overstate the $t$-statistics (Petersen 2009). For example, serial correlation, which we cannot fully control for, could be present in the investment behavior of serial acquirers. To address this potential problem, we cluster standard errors by acquiring firm in all of our regressions. ${ }^{5}$

We start with a parsimonious model that regresses abnormal returns on the key variable of interest, $\ln$ (Pay ratio). Column 1 of Table 4 reports the results. We find that the coefficient estimate of $\ln$ (Pay ratio) is negative and significant at the $1 \%$ level, suggesting a negative raw association between tournament incentives and acquisition performance. Next, we add executive-level and firm-level controls and report the results in Column 2. The coefficient estimate continues to be negative and is significant at the 5\% level. Finally, we add deal-level controls into the regression and find that the coefficient estimate of $\ln$ (Pay ratio) remains negative and significant at the $5 \%$ level, as reported in Column 3 . In terms of economic importance, we find that a 1-standard-deviation increase in the pay ratio centered on its sample mean reduces CAR by 22

We fully acknowledge that serial correlation in investment behavior may also exist among firms in the same industry. In Table A3 in the appendix, we rerun the baseline regressions using standard errors clustered by industry and industry-year. We continue to find a negative relation between tournament incentives and acquisition performance, but the statistical significance drops to the $10 \%$ level when clustering by industry-year. 
Table 4

Effect of tournament incentives on acquisition performance

(1)

(2)

(3)

$\operatorname{CAR}(-2,+2)$

\begin{tabular}{|c|c|c|c|}
\hline $\ln$ (Pay ratio) & $\begin{array}{c}-0.419 * * * \\
(-2.919)\end{array}$ & $\begin{array}{l}-0.370^{* *} \\
(-2.487)\end{array}$ & $\begin{array}{c}-0.354^{* *} \\
(-2.376)\end{array}$ \\
\hline $\ln (\mathrm{CEO}$ delta $)$ & & $\begin{array}{c}0.143 * * \\
(2.068)\end{array}$ & $\begin{array}{c}0.144 * * \\
(2.095)\end{array}$ \\
\hline $\ln (\mathrm{CEO}$ vega $)$ & & $\begin{array}{l}-0.104 * \\
(-1.905)\end{array}$ & $\begin{array}{l}-0.101^{*} \\
(-1.853)\end{array}$ \\
\hline CEO entrenchment & & $\begin{array}{c}-0.247 \\
(-0.832)\end{array}$ & $\begin{array}{c}-0.177 \\
(-0.599)\end{array}$ \\
\hline CEO turnover & & $\begin{array}{l}-0.430^{*} \\
(-1.848)\end{array}$ & $\begin{array}{c}-0.476^{* *} \\
(-2.045)\end{array}$ \\
\hline Number of VPs & & $\begin{array}{c}-0.074 \\
(-1.056)\end{array}$ & $\begin{array}{c}-0.069 \\
(-0.995)\end{array}$ \\
\hline VP acquisition experience & & $\begin{array}{c}0.041 \\
(1.111)\end{array}$ & $\begin{array}{c}0.044 \\
(1.187)\end{array}$ \\
\hline $\ln ($ Firm size $)$ & & $\begin{array}{c}-0.209 * * * \\
(-3.443)\end{array}$ & $\begin{array}{l}-0.156^{* *} \\
(-2.449)\end{array}$ \\
\hline Leverage & & $\begin{array}{c}1.095^{* *} \\
(2.036)\end{array}$ & $\begin{array}{c}0.869 \\
(1.593)\end{array}$ \\
\hline Tobin's q & & $\begin{array}{c}-0.209^{* *} \\
(-2.476)\end{array}$ & $\begin{array}{l}-0.184 * * \\
(-2.193)\end{array}$ \\
\hline Cash flow & & $\begin{array}{l}2.232 * \\
(1.788)\end{array}$ & $\begin{array}{c}1.873 \\
(1.511)\end{array}$ \\
\hline Firm governance & & $\begin{array}{c}0.028 \\
(0.124)\end{array}$ & $\begin{array}{c}-0.054 \\
(-0.244)\end{array}$ \\
\hline Stock price runup & & $\begin{array}{c}-1.157 * * * \\
(-5.467)\end{array}$ & $\begin{array}{c}-1.132 * * * \\
(-5.385)\end{array}$ \\
\hline Relative deal size & & & $\begin{array}{c}0.417 \\
(0.826)\end{array}$ \\
\hline Cross-industry & & & $\begin{array}{c}-0.107 \\
(-0.738)\end{array}$ \\
\hline Cross-border & & & $\begin{array}{c}-0.126 \\
(-0.746)\end{array}$ \\
\hline All-cash deal & & & $\begin{array}{c}0.481 * * * \\
(3.508)\end{array}$ \\
\hline Private target & & & $\begin{array}{c}1.318 * * * \\
(6.428)\end{array}$ \\
\hline Subsidiary target & & & $\begin{array}{c}1.863 * * * \\
(8.671)\end{array}$ \\
\hline M\&A wave & & & $\begin{array}{c}-0.036 \\
(-0.040)\end{array}$ \\
\hline Constant & $\begin{array}{c}2.700 * * * \\
(4.637)\end{array}$ & $\begin{array}{c}3.926 * * * \\
(3.808)\end{array}$ & $\begin{array}{c}2.045^{* *} \\
(2.010)\end{array}$ \\
\hline Year fixed effects & Yes & Yes & Yes \\
\hline Industry fixed effects & Yes & Yes & Yes \\
\hline No. of observations & 8,911 & 8,911 & 8,911 \\
\hline$R^{2}$ & .02 & .03 & .04 \\
\hline
\end{tabular}

This table reports the effect of tournament incentives on acquisition performance. We estimate the following baseline model specification:

$$
C A R_{i, t}=\alpha+\beta \text { LnPayRatio }_{i, t-1}+\gamma Z_{i, t-1}+\text { YearFE }+ \text { IndustryFE }+\varepsilon_{i, t} .
$$

Table A1 in the appendix defines all variables. $t$-statistics are calculated from robust standard errors clustered by firm and are displayed in parentheses. ${ }^{*} p<.1 ;{ }^{* *} p<.05 ;{ }^{* * *} p<.01$. 
basis points, which translates into a loss of $\$ 28.6$ million in shareholder value for the average acquirer in our sample. ${ }^{6}$

The coefficients of our control variables exhibit the expected signs. For example, CEOs who receive more equity-based compensation have more incentives to make value-enhancing acquisitions (Datta, Iskandar-Datta, and Raman 2001); managers in larger firms are more entrenched (large firm size serves as an effective takeover defense) and therefore are likely to make value-destroying acquisitions (Masulis, Xie, and Wang 2007); firms that are overvalued (higher Tobin's q) are likely to reveal their true value to the market on the announcement of an acquisition (Moeller, Schlingemann, and Stulz 2004); acquirers do worse when paying with equity due to the well-documented adverse selection problem (Myers and Maliuf 1984); and acquirers do better when acquiring private and subsidiary targets, because they capture a liquidity discount (Fuller, Netter, and Stegemoller 2002).

\subsection{Tournament incentives or CEO entrenchment?}

In this paper we use the pay ratio between the CEO and VPs as a measure of tournament incentives. However, prior studies (Bebchuk, Cremers, and Peyer 2011; Chen et al. 2013) have also interpreted the pay ratio as a measure of $\mathrm{CEO}$ power. Given that prior research finds that entrenched CEOs tend to make worse acquisitions (Masulis, Wang, and Xie 2007; Harford, Humphery-Jenner, and Powell 2012), it is also possible that our findings are actually driven by the entrenchment hypothesis rather than our tournament hypothesis. In addition to explicitly controlling for CEO entrenchment in all of our regressions, in this section we adopt a two-stage regression approach to further distinguish our tournament hypothesis from the CEO entrenchment hypothesis. Specifically, in the first stage we decompose the pay ratio measure into 2 parts, one part that proxies for CEO entrenchment and the residual part that more likely proxies for tournament incentives. Then, in the second stage, we use the residual part as our proxy for tournament incentives to examine the relationship between tournament incentives and acquisition performance.

Table 5 presents the results. Column 1 reports the results from the firststage regression. We see that the pay ratio is larger if the CEO is the only insider on the board. Columns 2 to 4 report the results from the secondstage regressions, where we regress announcement returns on the residuals from our first-stage regression, which more likely proxy for

6 The economic significance is easier to interpret when it is computed in terms of a 1-standard-deviation change in pay ratio rather than the natural logarithm of pay ratio. To achieve this, we first calculate the level of pay ratio that is 0.5 standard deviations below its mean (low pay ratio) and 0.5 standard deviations above its mean (high pay ratio). We then compute the difference between the natural logarithm of high pay ratio and the natural logarithm of low pay ratio. 
Table 5

Effect of tournament incentives on acquisition performance: CEO entrenchment hypothesis versus tournament hypothesis

\begin{tabular}{|c|c|c|c|c|}
\hline \multirow{2}{*}{$\begin{array}{l}\text { Dep. = CAR } \\
\text { Residuals }\end{array}$} & \multirow[t]{2}{*}{$\begin{array}{c}\text { First stage } \\
\ln (\text { Pay ratio) }\end{array}$} & \multicolumn{3}{|c|}{$\begin{array}{l}\text { Second stage } \\
\text { CAR }\end{array}$} \\
\hline & & $\begin{array}{l}-0.422 * * \\
(-2.380)\end{array}$ & $\begin{array}{l}-0.414 * * \\
(-2.325)\end{array}$ & $\begin{array}{c}-0.421 * * \\
(-2.368)\end{array}$ \\
\hline CEO Chair & $\begin{array}{c}0.027 \\
(1.141)\end{array}$ & & $\begin{array}{l}-0.119 \\
(-0.650)\end{array}$ & $\begin{array}{l}-0.133 \\
(-0.720)\end{array}$ \\
\hline $\mathrm{CEO}$ is the only insider director & $\begin{array}{c}0.135^{* * * *} \\
(5.646)\end{array}$ & & $\begin{array}{c}0.269 \\
(1.251)\end{array}$ & $\begin{array}{c}0.251 \\
(1.170)\end{array}$ \\
\hline CEO is highly tenured & $\begin{array}{c}-0.026 \\
(-0.948)\end{array}$ & & $\begin{array}{l}-0.148 \\
(-0.729)\end{array}$ & $\begin{array}{c}-0.136 \\
(-0.677)\end{array}$ \\
\hline CEO hubris & $\begin{array}{c}0.028 \\
(1.170)\end{array}$ & & $\begin{array}{l}0.086 \\
(0.405)\end{array}$ & $\begin{array}{l}0.103 \\
(0.481)\end{array}$ \\
\hline $\ln (\mathrm{CEO}$ delta $)$ & & & $\begin{array}{c}0.127 \\
(1.391)\end{array}$ & $\begin{array}{c}0.118 \\
(1.299)\end{array}$ \\
\hline $\ln (\mathrm{CEO}$ vega $)$ & & & $\begin{array}{c}-0.009 \\
(-0.146)\end{array}$ & $\begin{array}{c}-0.006 \\
(-0.092)\end{array}$ \\
\hline CEO turnover & & & $\begin{array}{l}-0.012 \\
(-0.046)\end{array}$ & $\begin{array}{l}-0.049 \\
(-0.181)\end{array}$ \\
\hline Number of VPs & & & $\begin{array}{c}0.059 \\
(0.759)\end{array}$ & $\begin{array}{c}0.064 \\
(0.828)\end{array}$ \\
\hline VP acquisition experience & & & $\begin{array}{c}0.058 \\
(1.200)\end{array}$ & $\begin{array}{c}0.058 \\
(1.221)\end{array}$ \\
\hline $\ln ($ Firm size $)$ & & & $\begin{array}{c}-0.354 * * * \\
(-4.357)\end{array}$ & $\begin{array}{c}-0.314 * * * \\
(-3.743)\end{array}$ \\
\hline Leverage & & & $\begin{array}{c}1.183 \\
(1.614)\end{array}$ & $\begin{array}{c}1.085 \\
(1.436)\end{array}$ \\
\hline Tobin's q & & & $\begin{array}{c}-0.275^{* * * *} \\
(-2.796)\end{array}$ & $\begin{array}{c}-0.260 * * * \\
(-2.654)\end{array}$ \\
\hline Cash flow & & & $\begin{array}{l}1.646 \\
(1.148)\end{array}$ & $\begin{array}{c}1.457 \\
(1.019)\end{array}$ \\
\hline Firm governance & & & $\begin{array}{c}-0.464 \\
(-1.434)\end{array}$ & $\begin{array}{c}-0.504 \\
(-1.564)\end{array}$ \\
\hline Stock price runup & & & $\begin{array}{c}-1.456 * * * \\
(-5.619)\end{array}$ & $\begin{array}{c}-1.449^{* * * *} \\
(-5.631)\end{array}$ \\
\hline Relative deal size & & & & $\begin{array}{c}0.334 \\
(0.493)\end{array}$ \\
\hline Cross-industry & & & & $\begin{array}{c}0.051 \\
(0.307)\end{array}$ \\
\hline Cross-border & & & & $\begin{array}{c}0.073 \\
(0.397)\end{array}$ \\
\hline All-cash deal & & & & $\begin{array}{c}0.381^{* *} \\
(2.369)\end{array}$ \\
\hline Private target & & & & $\begin{array}{c}0.876^{* * * *} \\
(3.353)\end{array}$ \\
\hline Subsidiary target & & & & $\begin{array}{c}1.547 * * * \\
(5.793)\end{array}$ \\
\hline M\&A wave & & & & $\begin{array}{c}2.179 \\
(1.527)\end{array}$ \\
\hline Constant & $\begin{array}{c}0.949 * * * \\
(13.470)\end{array}$ & $\begin{array}{c}1.197 * * * \\
(2.771)\end{array}$ & $\begin{array}{c}2.632 * * * \\
(3.121)\end{array}$ & $\begin{array}{l}1.160 \\
(1.322)\end{array}$ \\
\hline Year fixed effects & Yes & Yes & Yes & Yes \\
\hline Industry fixed effects & Yes & Yes & Yes & Yes \\
\hline No. of observations & 5,685 & 5,685 & 5,685 & 5,685 \\
\hline$R^{2}$ & .07 & .02 & .04 & .05 \\
\hline
\end{tabular}

This table reports the effect of tournament incentives on acquisition performance after decomposing the pay ratio measure into a part that proxies for CEO entrenchment and a part that proxies for tournament incentives Column 1 reports the result of the first stage, where the pay ratio is regressed on measures of $\mathrm{CEO}$ entrenchment. Columns 2 to 4 report results for the second stage, where abnormal returns are regressed on the residuals from the first stage, the part of the pay ratio that proxies for tournament incentives. Table Al in the appendix defines all variables. $t$-statistics are calculated from robust standard errors clustered by firm and are displayed in parentheses. ${ }^{*} p<.1 ; * *<.05 ; * * *<.01$. 
tournament incentives. We find results that are similar to our baseline regressions, indicating that the negative relation between pay gaps and acquisition performance is indeed driven by tournament incentives rather than CEO entrenchment.

\subsection{Acquisition propensity and deal risk}

Our evidence so far suggests that tournament incentives harm acquisition performance, and our risk-seeking hypothesis predicts that this effect is likely to be driven by high tournament incentive firms making more overly risky acquisitions. In this section, we first examine whether firms with higher tournament incentives are more likely to conduct acquisitions, and then we test whether the value destruction caused by tournament incentives are concentrated in overly risky deals.

We first run a logit model to examine the effect of tournament incentives on acquisition propensity. Column 1 of Table 6 shows the results. Indeed, we find that firms with higher tournament incentives are more likely to conduct acquisitions. Following Minnick, Unal, and Yang (2011) we then split acquisitions into those that are value enhancing and those that are value destroying based on their cumulative announcement returns and run a multinominal logit model. The dependent variable equals to one if a firm makes an acquisition and the announcement return is negative $(\mathrm{CAR}<0)$, and two if a firm makes an acquisition and the announcement return is positive $(\mathrm{CAR}>0)$. The dependent variable equals to zero for the benchmark nonacquirer sample. The results in Columns 2 and 3 of Table 6 show that firms with higher tournament incentives are more likely to conduct value-destroying acquisitions.

We then test whether the value destruction caused by tournament incentives are concentrated in extremely large and extremely risky deals, as these deals are likely to be the overly risky deals supported by the VPs due to their tournament incentives. First, we measure deal size using relative deal size (deal value divided by acquirer's market capitalization), and define deals in the 4th quartile in each year to be extremely large deals. Consistent with our prediction, Columns 1 and 2 of Table 7 show that the negative effect of tournament incentives is stronger for extremely large deals. Second, we follow Agrawal and Mandelker (1987) and use the change in the standard deviation of acquirers' stock returns surrounding the acquisition to proxy for deal risk. Specifically, deal risk is calculated as the difference in the acquirers' standard deviation of stock returns in the postacquisition period (11 to 70 days following the effective date) compared to the preacquisition period (120 days to 60 days prior to the announcement date). The preacquisition period ends 60 days before the announcement date and the post-acquisition period begins 11 days after the effective date in order to avoid the acquisition negotiation or completion period in 
Table 6

Effect of tournament incentives on decisions to acquire

(1)

\begin{tabular}{|c|c|c|c|}
\hline & $\operatorname{Pr}$ (Acquisition) & $\operatorname{Pr}(\mathrm{CAR}<0)$ & $\operatorname{Pr}(\mathrm{CAR}>0)$ \\
\hline \multirow[t]{2}{*}{$\ln$ (Pay ratio) } & $0.081 * *$ & $0.121 * * *$ & 0.044 \\
\hline & $(2.380)$ & $(2.717)$ & $(1.090)$ \\
\hline \multirow{2}{*}{$\ln ($ CEO delta $)$} & $0.047 * * *$ & 0.027 & $0.065 * * *$ \\
\hline & $(2.870)$ & $(1.260)$ & $(3.265)$ \\
\hline \multirow[t]{2}{*}{$\ln (\mathrm{CEO}$ vega $)$} & -0.001 & -0.006 & 0.005 \\
\hline & $(-0.134)$ & $(-0.565)$ & $(0.473)$ \\
\hline \multirow[t]{2}{*}{$\mathrm{CEO}$ entrenchment } & -0.094 & -0.038 & -0.144 \\
\hline & $(-1.011)$ & $(-0.325)$ & $(-1.271)$ \\
\hline \multirow[t]{2}{*}{ CEO turnover } & $-0.143^{* * *}$ & -0.107 & $-0.177 * *$ \\
\hline & $(-2.588)$ & $(-1.535)$ & $(-2.460)$ \\
\hline \multirow[t]{2}{*}{ Number of VPs } & $-0.117 * * *$ & $-0.099 * * *$ & $-0.134 * * *$ \\
\hline & $(-7.790)$ & $(-5.079)$ & $(-6.900)$ \\
\hline \multirow[t]{2}{*}{ VP acquisition experience } & $0.331 * * *$ & $0.317 * * *$ & $0.344 * * *$ \\
\hline & $(34.008)$ & $(26.923)$ & $(28.836)$ \\
\hline \multirow[t]{2}{*}{$\ln ($ Firm size $)$} & $0.112 * * *$ & $0.168 * * *$ & $0.056 * * *$ \\
\hline & $(6.628)$ & $(8.034)$ & (2.689) \\
\hline \multirow[t]{2}{*}{ Leverage } & $-0.943^{* * *}$ & $-0.942 * * *$ & $-0.951 * * *$ \\
\hline & $(-7.017)$ & $(-5.584)$ & $(-6.123)$ \\
\hline \multirow[t]{2}{*}{ Tobin's q } & 0.019 & $0.033 * *$ & -0.003 \\
\hline & $(1.576)$ & $(2.442)$ & $(-0.135)$ \\
\hline \multirow[t]{2}{*}{ Cash flow } & $0.724 * * *$ & $0.518 * *$ & $0.953 * * *$ \\
\hline & $(3.839)$ & $(2.165)$ & $(3.736)$ \\
\hline \multirow[t]{2}{*}{ Firm governance } & $0.392 * * *$ & $0.418 * * *$ & $0.371 * * *$ \\
\hline & (7.372) & $(6.157)$ & $(5.687)$ \\
\hline \multirow[t]{2}{*}{ Constant } & $-2.919^{* * *}$ & $-4.585^{* * *}$ & $-2.775^{* * *}$ \\
\hline & $(-7.495)$ & $(-7.015)$ & $(-6.810)$ \\
\hline Year fixed effects & Yes & Yes & Yes \\
\hline Industry fixed effects & Yes & Yes & Yes \\
\hline No. of observations & 26,530 & \multicolumn{2}{|c|}{26,530} \\
\hline Pseudo- $R^{2}$ & .13 & \multicolumn{2}{|c|}{.10} \\
\hline
\end{tabular}

This table reports the effect of tournament incentives on decisions to acquire. The dependent variable for the logit model in Column 1 equals one if the firm makes at least one acquisition in the year, and zero otherwise. The dependent variable for the multinomial logit model in Columns 2 and 3 equals one (two) if the firm makes at least one acquisition in the year and the deal value weighted average announcement returns is negative (positive), and zero if a firm makes no acquisition during the year. Table A1 in the appendix defines all variables. $t$-statistics are calculated from robust standard errors clustered by firm and are displayed in parentheses. ${ }^{*} p<.1 ; * * p<.05 ; * * * p<.01$.

affecting stock returns. We again sort the acquisitions into quartiles according to their level of risk and define deals in the 4 th quartile in each year to be extremely risky deals. Columns 3 and 4 of Table 7 present the results. Consistent with our predictions, we find that the negative effect of tournament incentives is strongest in extremely risky deals. ${ }^{7}$

\subsection{VP incentives}

The effectiveness of tournament incentives also depends on VPs' eagerness to compete in the promotion tournament, as holding a promotion

7 We repeat our analysis on deal size and deal risk using within-industry deals and show the results in Table A4 in the appendix. These additional tests allow us to focus on acquisitions occurring within respective industries. 
Table 7

Effect of tournament incentives on acquisition performance: Deal risk

(1) (2)

\begin{tabular}{|c|c|c|c|c|}
\hline & \multicolumn{2}{|c|}{ Deal size } & \multicolumn{2}{|c|}{ Deal risk } \\
\hline & Q1 - Q3 & Q4 & Q1 - Q3 & Q4 \\
\hline \multirow[t]{3}{*}{$\ln$ (Pay ratio) } & -0.102 & $-1.325 * * *$ & -0.148 & $-0.975 * * *$ \\
\hline & $(-0.673)$ & $(-3.364)$ & $(-0.871)$ & $(-3.136)$ \\
\hline & \multicolumn{2}{|c|}{$\begin{array}{c}\mathrm{H} 0: \begin{array}{c}\beta(1)=\beta(2) \\
(0.003)\end{array}\end{array}$} & \multicolumn{2}{|c|}{$\begin{array}{c}\mathrm{H} 0: \begin{array}{c}\beta(3)=\beta(4) \\
(0.018)\end{array}\end{array}$} \\
\hline \multirow[t]{2}{*}{$\ln (\mathrm{CEO}$ delta $)$} & 0.073 & $0.342 *$ & 0.114 & $0.259^{*}$ \\
\hline & $(1.090)$ & (1.819) & $(1.439)$ & $(1.771)$ \\
\hline \multirow[t]{2}{*}{$\ln (\mathrm{CEO}$ vega $)$} & -0.026 & -0.234 & -0.080 & -0.184 \\
\hline & $(-0.506)$ & $(-1.538)$ & $(-1.339)$ & $(-1.566)$ \\
\hline \multirow[t]{2}{*}{ CEO entrenchment } & -0.131 & -0.158 & -0.428 & 0.612 \\
\hline & $(-0.436)$ & $(-0.208)$ & $(-1.275)$ & $(0.952)$ \\
\hline \multirow[t]{2}{*}{ CEO turnover } & -0.287 & $-1.279^{* *}$ & $-0.535^{* *}$ & -0.416 \\
\hline & $(-1.184)$ & $(-2.209)$ & $(-2.012)$ & $(-0.817)$ \\
\hline \multirow[t]{2}{*}{ Number of VPs } & -0.018 & -0.188 & -0.066 & -0.065 \\
\hline & $(-0.256)$ & $(-1.179)$ & $(-0.838)$ & $(-0.458)$ \\
\hline \multirow[t]{2}{*}{ VP experience } & $0.077 * *$ & -0.028 & 0.046 & 0.042 \\
\hline & $(2.054)$ & $(-0.304)$ & $(1.058)$ & $(0.575)$ \\
\hline \multirow[t]{2}{*}{$\ln$ (Firm size) } & -0.089 & $-0.322^{*}$ & $-0.175^{* *}$ & -0.083 \\
\hline & $(-1.414)$ & $(-1.877)$ & $(-2.467)$ & $(-0.632)$ \\
\hline \multirow[t]{2}{*}{ Leverage } & 0.115 & $2.105^{*}$ & $1.190^{*}$ & -0.191 \\
\hline & $(0.213)$ & $(1.771)$ & $(1.907)$ & $(-0.178)$ \\
\hline \multirow[t]{2}{*}{ Tobin's q } & $-0.199 * * *$ & 0.007 & $-0.223^{* *}$ & -0.089 \\
\hline & $(-2.593)$ & $(0.026)$ & $(-2.402)$ & $(-0.517)$ \\
\hline \multirow[t]{2}{*}{ Cash flow } & 1.935 & 2.588 & $2.387 *$ & 0.566 \\
\hline & $(1.533)$ & $(0.878)$ & $(1.651)$ & $(0.248)$ \\
\hline \multirow[t]{2}{*}{ Firm governance } & -0.313 & $0.963^{*}$ & -0.070 & 0.154 \\
\hline & $(-1.404)$ & $(1.832)$ & $(-0.288)$ & $(0.327)$ \\
\hline \multirow[t]{2}{*}{ Stock price runup } & $-0.834 * * *$ & $-1.757^{* * *}$ & $-1.269 * * *$ & $-0.770^{*}$ \\
\hline & $(-3.850)$ & $(-3.936)$ & $(-5.294)$ & $(-1.810)$ \\
\hline \multirow[t]{2}{*}{ Relative deal size } & $4.363^{*}$ & -0.002 & 0.499 & 0.233 \\
\hline & $(1.821)$ & $(-0.003)$ & $(0.895)$ & $(0.210)$ \\
\hline \multirow[t]{2}{*}{ Cross-industry } & 0.046 & -0.593 & -0.026 & -0.453 \\
\hline & $(0.328)$ & $(-1.474)$ & $(-0.157)$ & $(-1.561)$ \\
\hline \multirow[t]{2}{*}{ Cross-border } & -0.130 & 0.422 & -0.191 & 0.086 \\
\hline & $(-0.770)$ & $(0.834)$ & $(-1.077)$ & $(0.220)$ \\
\hline \multirow[t]{2}{*}{ All-cash deal } & 0.204 & $0.957 * *$ & $0.504 * * *$ & 0.440 \\
\hline & $(1.485)$ & $(2.562)$ & $(3.241)$ & $(1.546)$ \\
\hline \multirow[t]{2}{*}{ Private target } & $0.567 * * *$ & $2.615^{* * *}$ & $1.332 * * *$ & $1.216 * *$ \\
\hline & $(2.807)$ & $(5.326)$ & $(5.972)$ & $(2.497)$ \\
\hline Subsidiary target & $0.858 * * *$ & $3.512 * * *$ & $1.726 * * *$ & $2.288 * * *$ \\
\hline & $(4.057)$ & $(7.659)$ & $(7.595)$ & $(4.460)$ \\
\hline M\&A wave & 0.095 & -1.135 & 0.776 & -1.592 \\
\hline & $(0.109)$ & $(-0.404)$ & $(0.769)$ & $(-0.895)$ \\
\hline Constant & 0.141 & $13.882 * * *$ & $2.222^{*}$ & 1.558 \\
\hline & $(0.077)$ & $(6.657)$ & (1.946) & $(1.127)$ \\
\hline Year fixed effects & Yes & Yes & Yes & Yes \\
\hline Industry fixed effects & Yes & Yes & Yes & Yes \\
\hline No. of observations & 6,684 & 2,227 & 6,684 & 2,227 \\
\hline$R^{2}$ & .02 & .13 & .05 & .06 \\
\hline
\end{tabular}

This table reports the effect of tournament incentives on acquisition performance conditional upon deal risk. Deal size is measured as the relative deal size. Deal risk is measured as the post-acquisition minus preacquisition stock return standard deviations. Table A1 in the appendix defines all variables. $t$-statistics are calculated from robust standard errors clustered by firm and are displayed in parentheses. ${ }^{*} p<$ $.1 ; * *<.05 ; * * *<.01$. 
tournament would have no value at all if none of the VPs are going to compete in the tournament. Hence, we expect the effect of tournament incentives on acquisition performance to be stronger in firms where VPs are more eager to compete in a promotion tournament.

First, VPs are more eager to compete in the promotion tournament if they believe that the board is likely to hire the next CEO internally. Anecdotal evidence suggests that firms' decision to hire CEOs internally tends to be sticky. For example, Hewlett-Packard was hiring its CEO internally for the first 52 years of its operations (Larcker and Tayan 2011). Hence, we expect that VPs are more likely to take excessive risks if the current CEO was hired internally, because VPs are more likely to believe that the firm is going to continue with a similar senior recruitment strategy and will also hire the next CEO internally. We define internally hired CEOs as those who have been working for a firm prior to becoming CEO. Columns 1 and 2 of Table 8 report the results. We find that the negative effect of tournament incentives on acquisition performance only occurs in firms in which the current CEO has been promoted from within.

Second, theoretical models predict that only players who are significantly behind in a tournament have the incentives to take excessive risks to catch up to the tournament leaders, because players who are ranked relatively close to each other only have to increase their performance by a small margin to outperform the other player to claim the tournament prize (Hvide 2002; Fang, Noe, and Strack 2019). Similarly, in a recent empirical study that investigates succession tournaments in Korean family firms, Lee, Shin, and Yun (2018) find that succession tournaments result in excessive risk-taking. They find that the lagging sons would take excessive risks in order to catch up to the leading son in succession tournaments, and the leading son would mimic the lagging sons' strategy to preserve his lead, resultant overall in excessive corporate risk-taking. Based on these past findings, we expect firms in which VPs' pay are highly dispersed are more likely to conduct excessive risky acquisitions, because the lagging VPs would try to maximize corporate risk-taking to catch up to the leading VP by supporting the CEO in making extremely risky acquisitions. At the same time, the leading VP would try to maintain the lead by conducting the same action as the laggers, which results in all of the VPs collectively advocating extremely risky acquisitions. Columns 3 and 4 of Table 8 report the results. We find that the negative effect of tournament incentives on acquisition performance is stronger in firms where VP pay is highly dispersed.

Third, VPs should be less eager to compete in a promotion tournament in firms operating in industries with a high level of industry concentration and high degree of product similarity as the probability of an internal promotion is likely to be lower within these firms, because outsiders 


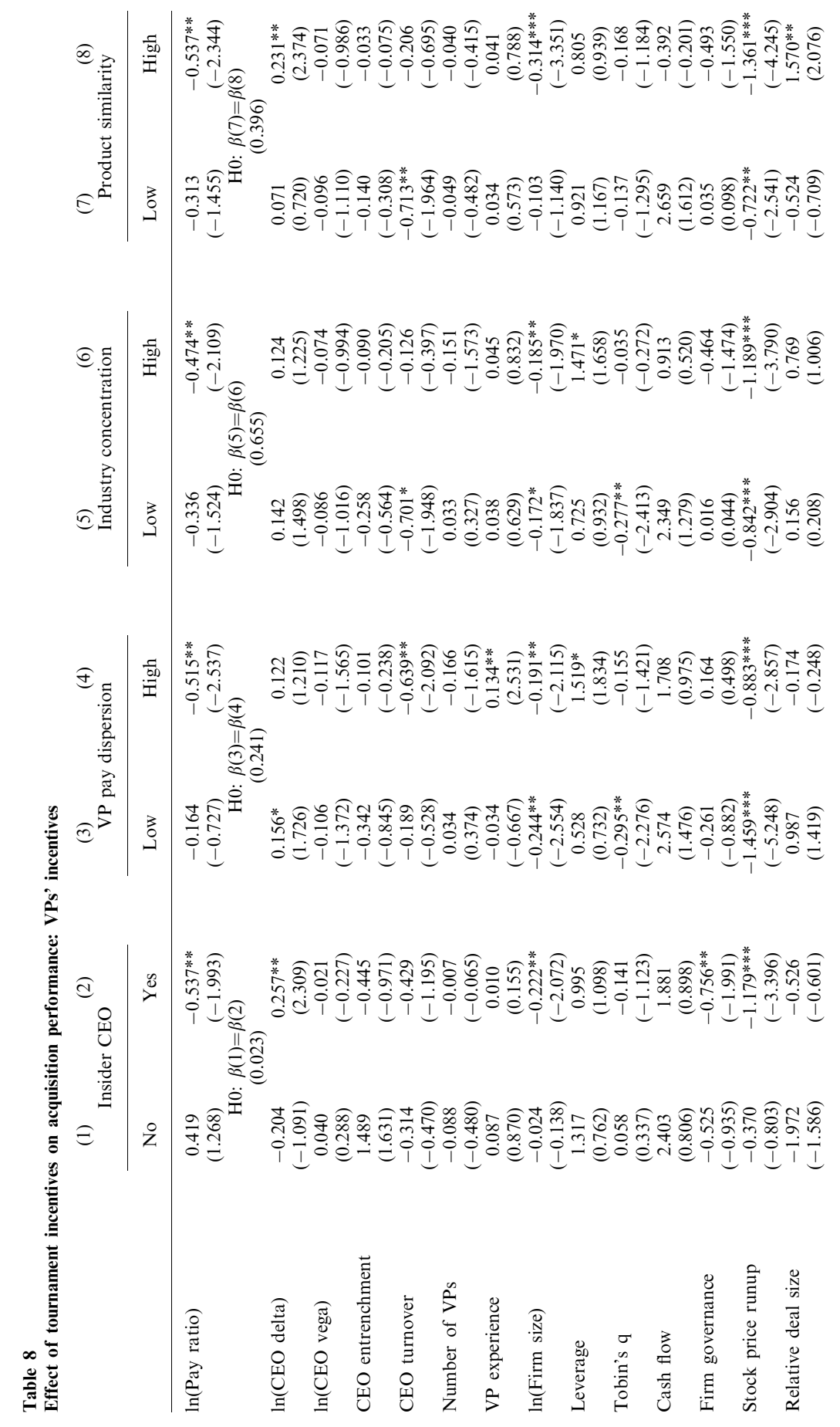




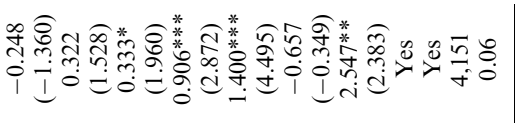

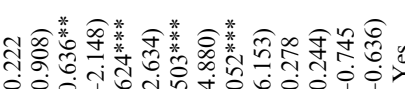

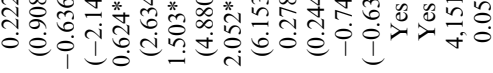

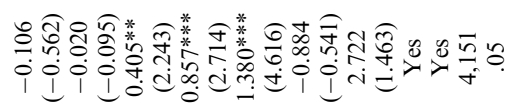

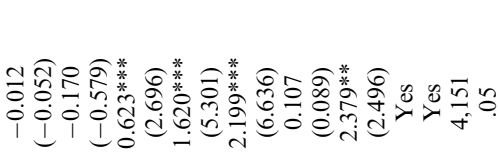

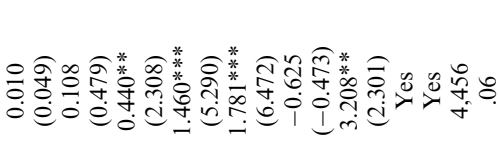

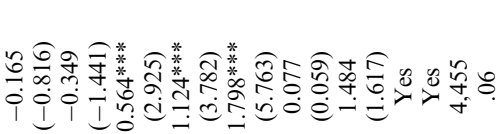

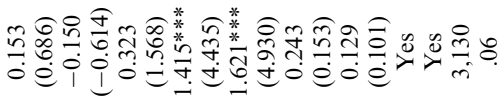

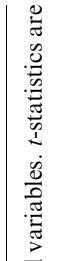

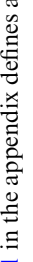

.

है

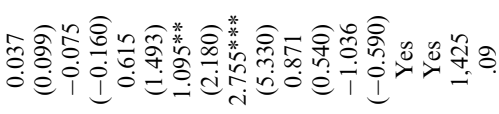

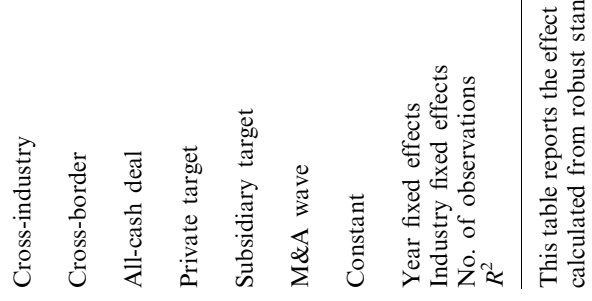


can also compete for the CEO's job, and also it is easier for VPs to look for outside opportunities in these industries. We source firm-level industry concentration and product similarity proxies from Hoberg and Phillips (2016) and report the subsample results in Columns 5 to 8 of Table $8 .{ }^{8}$ Consistent with our predictions we find that the effect of tournament incentives on acquisition performance is significantly weaker in firms operating in industries with higher levels of industry concentration and higher degrees of product similarity, as VPs working in these industries are conceivably less likely to compete aggressively in a promotion tournament. The combination of VPs' own enhanced outside promotion opportunities within the industry (as their professional networks are likely to be stronger and/or their expertise and skill sets are most highly valued and transferable) and the greater external competition faced for the internal promotion is likely to weaken tournament incentives within these corporate environments.

\section{Identification}

A potential endogeneity issue that may affect our baseline results is the omitted variables bias. Even after controlling for several known CEO, firm, and deal characteristics and year and industry fixed effects, there may still be unobservable firm or CEO heterogeneity correlated with both the pay gap and acquisition performance, and these factors could bias our results. As both tournament and $\mathrm{CEO}$ incentive measures are related to managerial compensation, $\ln (\mathrm{Pay}$ gap $), \ln (\mathrm{CEO}$ delta), and $\ln (C E O$ vega $)$ could all be endogenous. In this section, we address the endogeneity concern using two alternative approaches, although we are conscious of the fact that they can only ease, but not completely solve, the endogeneity problem due to the lack of natural experiments (direct exogenous shocks) in the executive compensation literature (Adams, Hermalin, and Weisbach 2010; Coles, Lemmon, and Meschke 2012; Edmans, Gabaix, and Jenter 2017).

\subsection{Instrumental variable analysis}

First, we employ an instrumental variables (IV) approach to address the potential endogeneity concern. Knyazeva, Knyazeva, and Masulis (2013) show that the proximity to large pools of local director talent leads to significantly more independent boards, indicating that executives tend to stay and work in the same geographical area throughout their career. Additionally, executives are most likely to switch between similar sized firms in the same industry as Murphy (1999) documents that the level of

8 See Hoberg and Phillips (2016) for details on the construction of these proxies. 
managerial compensation varies by firm size and industry. Taking into account these criteria, we instrument tournament incentives with "Local supply of VPs." Local supply of VPs is calculated as the sum of total number of VPs working in firms headquartered in the same ZIP code (obtained from 10-k filings), same size quartile and the same FamaFrench 49 industry as the acquirer in the year before the acquisition. We expect the local supply of VPs to be positively correlated to the pay ratio, as the excess supply of VPs are likely to increase the bargaining power of corporations, thereby leading to a further increase in the pay gap between the CEO and VPs. On the other hand, we do not expect the level of the local supply of VPs to directly affect any particular firm's acquisition performance. In addition to using the local supply of VPs as an instrument, we also follow Kale, Reis, and Venkateswaran (2009) and Kini and Williams (2012) and use the average tournament incentives and CEO incentives for firms in the same industry and in the same size quartile as the acquirer to instrument for tournament incentives and CEO incentives, respectively.

Table 9 presents the two-stage least squares (2SLS) regression results. Columns 1 to 3 report the results from the first-stage regressions for the three endogenous variables. We include the same set of controls as the baseline regressions and year and industry fixed effects with standard errors clustered by acquiring firm. Column 1 shows that the level of local supply of VPs and size-adjusted industry average values of tournament incentives are positively correlated with the firm's tournament incentives, and Columns 2 and 3 show that size-adjusted industry average values of CEO incentives are positively correlated with the firm's CEO incentives, affirming the validity of these instruments used.

Column 4 reports the results from the second-stage regression. Our main tournament variable $\ln$ (Pay ratio) and the two CEO incentive variables $\ln (C E O$ delta) and $\ln (C E O$ vega $)$ are all replaced by their fitted values from the first-stage regressions. We find that the coefficient estimate of $\ln$ (Pay ratio) is negative and statistically significant at the $5 \%$ level, which supports our risk-seeking hypothesis. In addition to the regression results, we also report the F-statistics for our first-stage regressions and the Anderson-Rubin F-statistics for our second-stage regression to show that the instruments are relevant and present the statistics from the Hansen-Sargan test of overidentifying restrictions to show that our instruments are valid. ${ }^{9}$

9 The reported magnitude of the tournament effect is 11 times larger in the IV estimations compared with the baseline results, which is a common problem in empirical studies as documented by Jiang (2017). Hence, we focus our economic interpretation on the baseline estimates, as they provide a lower bound on the likely effect of tournament incentives. 
Table 9

Effect of tournament incentives on acquisition performance: 2SLS results

(3)

(4)

First stage

$\ln$ (Pay ratio)

$\ln (\mathrm{CEO}$ delta $)$

$\ln$ (Pay ratio)

$\ln$ (CEO delta)

$\ln (\mathrm{CEO}$ vega $)$

Second-stage CAR

$\ln ($ CEO vega $)$

Local supply of VPs

$0.618 * *$
$(2.293)$
$0.297 * * *$
$(3.515)$
$0.104 * * *$

(2.748)

$-0.060^{*}$

$\ln ($ Industry average CEO vega)

$(-1.794)$

CEO entrenchment

$0.160 * * *$

(4.321)

CEO turnover

Number of VPs

$(-2.708)$

$0.013^{*}$

(1.785)

0.004

(1.010)

0.000

$(0.017)$

$-0.003$

Leverage

Tobin's q

$(-0.046)$

0.001

(0.092)

Cash flow

$-0.039$

$(-0.293)$

$0.110^{* * * *}$

(3.910)

$-0.031^{* *}$

Stock price runup

Relative deal size

$(-2.011)$

0.030

(1.076)

0.012

$(0.907)$

0.007

(0.469)

Cross-border

$-0.006$

All-cash deal

$(-0.511)$

$-0.021$

$(-1.229)$

$-0.012$

Subsidiary target

$(-0.710)$

$0.289 * * *$

(2.639)

$-0.186$

$(-1.126)$

Yes

Yes

Industry fixed effects

F-statistics

$8.99 * * *$

$-1.537^{* *}$
$(-2.124)$
0.189
$(0.764)$
$0.487 * * *$
$(5.717)$

$1.396^{*}$

(1.782)

$-0.336$

$(-1.339)$

$-0.312^{* * *}$

$(-2.720)$

$-0.219 * * *$

$(-3.276)$

$0.998 * * *$

(11.340)

$-0.055$

$(-1.124)$

$-0.096^{* * *}$

$(-5.687)$

$0.044 * * *$

(3.569)

$0.358 * * *$

(10.399)

$-0.631 * * *$

$(-3.590)$

$0.345 * * *$

(17.580)

$-0.742 * *$

$(-2.123)$

$-0.185^{* * *}$

$(-2.686)$

-0.070 **

$(-2.185)$

$-0.169 * * *$

0.006

$(0.173)$

$-0.019$

$(-0.598)$

0.008

$(0.290)$

$-0.013$

$(-0.318)$

$-0.026$

$(-0.614)$

0.115

$(0.483)$

0.043

(0.122)

Yes

Yes

Anderson-Rubin F-statistics

$98.85^{* * *}$

$0.566^{* * *}$

(5.825)

$0.487 * * *$

(4.537)

$-0.089$

$(-1.329)$

$-0.024$

$(-1.092)$

$0.025 * *$

(2.009)

$0.446^{* * *}$

(12.005)

$-0.717^{* * * *}$

$(-3.406)$

$0.076^{* * *}$

(2.832)

$-1.373^{* * *}$

$(-3.681)$

$0.392 * * *$

(5.143)

0.020

(0.510)

$-0.038$

$(-0.459)$

0.034

(0.879)

0.011

(0.268)

$0.076^{* *}$

(2.122)

$-0.050$

$(-0.998)$

$-0.054$

$(-1.085)$

0.317

(0.993)

0.409

(0.747)

Yes

Yes

$69.42 * * *$

0.432

(0.615)

$-0.768^{* * *}$

$(-2.721)$

$-0.013$

$(-0.127)$

0.060

(1.205)

0.017

$(0.042)$

0.761

(0.900)

$-0.195$

$(-0.845)$

1.273

(0.806)

0.511

(1.245)

$-1.230 * * *$

$(-5.415)$

0.528

(1.011)

$-0.061$

$(-0.392)$

$-0.093$

$(-0.517)$

$0.468^{* * *}$

(3.185)

$1.223^{* * *}$

(5.601)

$1.804 * * *$

(8.092)

1.268

(1.108)

3.640 **

(2.206)

Yes

Yes

$9.82 * *$

$0.31(.58)$

No. of observations

8,911

8,911

8,911

8,911

This table reports the 2SLS regressions of tournament incentives on acquisition performance. Columns 1 to 3 report the result of the first stage, where tournament, alignment, and risk-taking incentives are regressed on instrumental variables. Column 4 reports results for the second stage, where cumulative abnormal returns are regressed over the instrumented tournament, alignment, and risk-taking incentives. Table $\mathrm{A} 1$ in the appendix defines all variables. $t$-statistics are calculated from robust standard errors clustered by firm and are displayed in parentheses. ${ }^{*} p<.1 ;{ }^{*} p<.05 ; * * *<.01$. 


\subsection{Propensity-score matching}

Although the instrumental variables are widely used in the literature (Kale, Reis, and Venkateswaran 2009; Kini and Williams 2012), one concern is that when an industry specific shock occurs it can jointly affect both M\&A activities and compensation levels of CEOs and VPs within an industry. That is, even though the industry median levels of managerial compensation do not have a direct effect on a firm's acquisition performance, the occurrence of an industry shock may cause a correlation between industry median levels of managerial compensation and a firm's acquisition performance and threaten the validity of our instrumental variable analysis (Gormley and Matsa 2014). Hence, in our second approach to address the endogeneity problem, we follow the recent work of Shen and Zhang (2018) and conduct regression analysis on a propensity-score matched sample, in which firms with high tournament incentives are matched with firms with low tournament incentives to control for the systematic differences in firm and deal characteristics across these two groups.

To construct the matched sample, we first estimate a probit regression in which the dependent variable is High pay ratio. This is an indicator variable that takes a value equal to one if the acquirer's pay ratio is above the median and zero if the acquirer's pay ratio is below the median. The independent variables in our probit regression includes all firm characteristics that may determine firm-specific pay ratios. This regression generates a predicted probability of being a high-pay-ratio firm for each observation, which is called the propensity score. Second, we match each treatment firm (a firm with high pay ratio) with a matching control firm (a firm with low pay ratio) drawn from the same year and FamaFrench 49 industry and has the closest propensity score within a caliper of $1 \%$ (and $5 \%$ as a robustness check). Using the matched firm sample, we conduct the baseline regressions using the new indicator variable High pay ratio. Table 10 presents the regression results. The coefficients for High pay ratio are negative and significant at the 5\% level.

\section{Robustness Tests}

In this section, we discuss the results of an array of additional robustness tests. These robustness tests relate to alternative constructs to proxy for tournament incentives, the inclusion of VP equity incentives as additional controls, individually controlling for different firm governance aspects, and excluding firms with no VPs on the board from our sample.

First, tournament incentives may be dependent on the number of contestants in the tournament. To control for this potential bias, we conduct our analysis using the natural logarithm of pay ratio divided by the 
Table 10

Effect of tournament incentives on acquisition performance: Matched sample

(1)

(2)

(3)

(4)

\begin{tabular}{|c|c|c|c|c|}
\hline \multirow[b]{2}{*}{ High pay ratio } & \multicolumn{2}{|c|}{ Caliper $=1 \%$} & \multicolumn{2}{|c|}{ Caliper $=5 \%$} \\
\hline & $\begin{array}{c}-0.579 * * \\
(-2.134)\end{array}$ & $\begin{array}{c}-0.603^{* *} \\
(-2.259)\end{array}$ & $\begin{array}{c}-0.580^{* *} \\
(-2.203)\end{array}$ & $\begin{array}{c}-0.604 * * \\
(-2.334)\end{array}$ \\
\hline $\ln (\mathrm{CEO}$ delta $)$ & $\begin{array}{c}0.152 \\
(1.008)\end{array}$ & $\begin{array}{c}0.214 \\
(1.432)\end{array}$ & $\begin{array}{c}0.184 \\
(1.282)\end{array}$ & $\begin{array}{l}0.233^{*} \\
(1.649)\end{array}$ \\
\hline $\ln ($ CEO vega $)$ & $\begin{array}{l}-0.139 \\
(-1.168)\end{array}$ & $\begin{array}{l}-0.154 \\
(-1.312)\end{array}$ & $\begin{array}{l}-0.147 \\
(-1.289)\end{array}$ & $\begin{array}{l}-0.160 \\
(-1.419)\end{array}$ \\
\hline CEO entrenchment & $\begin{array}{c}0.406 \\
(0.681)\end{array}$ & $\begin{array}{c}0.416 \\
(0.700)\end{array}$ & $\begin{array}{c}0.380 \\
(0.663)\end{array}$ & $\begin{array}{c}0.393 \\
(0.691)\end{array}$ \\
\hline CEO turnover & $\begin{array}{l}-0.234 \\
(-0.553)\end{array}$ & $\begin{array}{l}-0.223 \\
(-0.517)\end{array}$ & $\begin{array}{l}-0.094 \\
(-0.230)\end{array}$ & $\begin{array}{l}-0.086 \\
(-0.207)\end{array}$ \\
\hline Number of VPs & $\begin{array}{r}-0.047 \\
(-0.364)\end{array}$ & $\begin{array}{l}-0.060 \\
(-0.471)\end{array}$ & $\begin{array}{l}-0.049 \\
(-0.389)\end{array}$ & $\begin{array}{l}-0.061 \\
(-0.481)\end{array}$ \\
\hline VP experience & $\begin{array}{c}0.134 \\
(1.624)\end{array}$ & $\begin{array}{l}0.136^{*} \\
(1.651)\end{array}$ & $\begin{array}{c}0.130 \\
(1.636)\end{array}$ & $\begin{array}{l}0.132^{*} \\
(1.678)\end{array}$ \\
\hline $\ln ($ Firm size $)$ & $\begin{array}{c}-0.359 * * * * \\
(-2.879)\end{array}$ & $\begin{array}{l}-0.254^{*} \\
(-1.939)\end{array}$ & $\begin{array}{c}-0.387^{* * *} \\
(-3.183)\end{array}$ & $\begin{array}{c}-0.288^{* *} \\
(-2.250)\end{array}$ \\
\hline Leverage & $\begin{array}{l}1.709^{*} \\
(1.664)\end{array}$ & $\begin{array}{c}0.967 \\
(0.942)\end{array}$ & $\begin{array}{l}1.755^{*} \\
(1.746)\end{array}$ & $\begin{array}{c}1.098 \\
(1.095)\end{array}$ \\
\hline Tobin's q & $\begin{array}{l}-0.031 \\
(-0.223)\end{array}$ & $\begin{array}{c}0.017 \\
(0.116)\end{array}$ & $\begin{array}{l}-0.033 \\
(-0.245)\end{array}$ & $\begin{array}{c}0.011 \\
(0.079)\end{array}$ \\
\hline Cash flow & $\begin{array}{c}2.287 \\
(1.009)\end{array}$ & $\begin{array}{c}1.627 \\
(0.712)\end{array}$ & $\begin{array}{c}1.887 \\
(0.849)\end{array}$ & $\begin{array}{c}1.205 \\
(0.538)\end{array}$ \\
\hline Firm governance & $\begin{array}{c}0.027 \\
(0.060)\end{array}$ & $\begin{array}{l}-0.096 \\
(-0.207)\end{array}$ & $\begin{array}{l}-0.065 \\
(-0.152)\end{array}$ & $\begin{array}{l}-0.174 \\
(-0.403)\end{array}$ \\
\hline Stock price runup & $\begin{array}{c}-0.915 * * \\
(-2.245)\end{array}$ & $\begin{array}{c}-0.875^{* *} \\
(-2.145)\end{array}$ & $\begin{array}{c}-0.883 * * \\
(-2.185)\end{array}$ & $\begin{array}{c}-0.858^{* * *} \\
(-2.120)\end{array}$ \\
\hline Relative deal size & & $\begin{array}{c}3.288 * * * \\
(2.758)\end{array}$ & & $\begin{array}{c}2.825 * * \\
(2.401)\end{array}$ \\
\hline Cross-industry & & $\begin{array}{c}0.248 \\
(0.832)\end{array}$ & & $\begin{array}{c}0.300 \\
(1.029)\end{array}$ \\
\hline Cross-border & & $\begin{array}{c}0.150 \\
(0.465)\end{array}$ & & $\begin{array}{c}0.071 \\
(0.222)\end{array}$ \\
\hline All-cash deal & & $\begin{array}{c}0.143 \\
(0.546)\end{array}$ & & $\begin{array}{c}0.144 \\
(0.561)\end{array}$ \\
\hline Private target & & $\begin{array}{c}1.460^{* * * *} \\
(3.561)\end{array}$ & & $\begin{array}{c}1.394 * * * \\
(3.535)\end{array}$ \\
\hline Subsidiary target & & $\begin{array}{c}2.042 * * * * \\
(4.869)\end{array}$ & & $\begin{array}{c}1.988^{* * * *} \\
(4.883)\end{array}$ \\
\hline M\&A wave & & $\begin{array}{l}-1.560 \\
(-0.866)\end{array}$ & & $\begin{array}{l}-1.131 \\
(-0.672)\end{array}$ \\
\hline Constant & $\begin{array}{c}6.246 * * * \\
(3.039)\end{array}$ & $\begin{array}{c}3.274 \\
(1.540)\end{array}$ & $\begin{array}{c}4.906 * * * \\
(2.849)\end{array}$ & $\begin{array}{c}2.272 \\
(1.267)\end{array}$ \\
\hline Year fixed effects & Yes & Yes & Yes & Yes \\
\hline Industry fixed effects & Yes & Yes & Yes & Yes \\
\hline No. of observations & 2,316 & 2,316 & 2,402 & 2,402 \\
\hline$R^{2}$ & .06 & .07 & .06 & .07 \\
\hline
\end{tabular}

This table reports the effect of tournament incentives on acquisition performance using a matched sample. To construct this matched sample, we first estimate the following probit regression: the dependent variable (High pay gap) equals one if a firm's pay gap is above the median, and zero if a firm's pay gap is below the median; the independent variables are various firm characteristics. The predicted likelihood is the propensity score. We then match each treatment firm (a firm with high pay gap) with a matching firm (a firm with low pay gap) drawn from the same year and industry and have the closest propensity score within a caliper of $1 \%$ (and $5 \%$ ). Table A1 in the appendix defines all variables. $t$ statistics are calculated from robust standard errors clustered by firm and are displayed in parentheses. $* p<.1 ; * * p .05 ; * * * p<.01$. 
number of VPs as a proxy for tournament incentives. Column 1 of Table 11 reports the results. Our prior findings remain unchanged. Second, we follow Kini and Williams (2012) and repeat our analysis using the difference between the CEO's pay and the median VP pay as an alternative proxy for tournament incentives. Results in Column 2 of Table 11 show that our results continue to hold. Third, rather than combining governance variables into a single index and controlling for the index, we now individually control for board independence, board size, and institutional ownership (Masulis and Zhang 2018). The adverse effect of tournament incentives on firms' acquisition performance continues to hold despite the significant reduction in sample size. Fourth, in all of our tests so far, we have assumed that all VPs have the same likelihood to be named the next $\mathrm{CEO}$ and the potential pay rise from becoming the next CEO is the only incentive driving VPs. However, VPs with better ability are more likely to become the next CEO, and hence this may potentially bias our results. To explicitly account for the influence of VP ability, we furthermore control for the standard deviation of VP ability in our regressions. Following Fredaseyu, Linck, and Wagner (2018), VP ability is calculated using the combination of VPs' educational background and professional experience. ${ }^{10}$ Similarly, VPs may have other incentives in addition to becoming the next CEO. For example, Coakley and Iliopoulou (2006) show that VPs often receive pay increases after completing an acquisition, and this may represent another incentive for VPs to support an acquisition. VPs have alignment and risktaking incentives associated with the firm's stock performance, and these incentives also could be driving their decisions in choosing suitable acquisition targets. VPs may also have better outside opportunities that offer higher compensation, and this may affect their incentive to participate in the tournament. We address these possibilities by controlling for the average VP pay increases after the acquisition, average VP delta and vega, the ratio between the fraction of equity compensation of the CEO and the fraction of average equity compensation of VPs, and the ratio between average VP pay within the firm and average VP pay for firms in the same industry and same size quartile as the firm. Column 4 of Table 11 reports the results with these additional controls added. We continue to find a negative effect of tournament incentives on acquisition performance. Fifth, we exclude firms with no VPs on the board, because VPs in these firms are less likely to play a significant role in acquisitions.

10 Following Fredaseyu, Linck, and Wagner (2018), education background contains information on whether a VP holds undergraduate, graduate, and/or MBA degrees. Professional experience contains information on whether a VP has legal/consulting experience, academic experience, accounting/finance experience, and/or management experience. VP ability score is calculated as the sum of these seven variables. We were unable to obtain consistent information from BoardEx for our sample firms on the other two variables used in Fredaseyu, Linck, and Wagner (2018), political and military experience, so we do not include these dimensions in our VP ability score. 
Table 11

Effect of tournament incentives on acquisition performance: Robustness results

\begin{tabular}{|c|c|c|c|c|c|}
\hline & (1) & (2) & (3) & (4) & $\begin{array}{l}\text { Exclude firms with no } \\
\text { VPs on the board }\end{array}$ \\
\hline $\ln$ (Pay ratio) & & & $\begin{array}{c}-0.455^{* * * *} \\
(-2.749)\end{array}$ & $\begin{array}{c}-0.447 * * \\
(-2.160)\end{array}$ & $\begin{array}{c}-0.648 * * * \\
(-2.688)\end{array}$ \\
\hline $\ln$ (Pay ratio/number of VPs) & $\begin{array}{c}-0.350 * * \\
(-2.345)\end{array}$ & & & & \\
\hline $\ln ($ Pay gap $)$ & & $\begin{array}{c}-0.170 * * \\
(-2.191)\end{array}$ & & & \\
\hline Board independence & & & $\begin{array}{c}0.030 \\
(0.051)\end{array}$ & $\begin{array}{c}1.097 \\
(1.540)\end{array}$ & $\begin{array}{c}0.570 \\
(0.702)\end{array}$ \\
\hline Board size & & & $\begin{array}{c}-0.007 \\
(-0.190)\end{array}$ & $\begin{array}{c}0.028 \\
(0.717)\end{array}$ & $\begin{array}{c}0.038 \\
(0.907)\end{array}$ \\
\hline Institutional ownership & & & $\begin{array}{l}-0.264 \\
(-0.507)\end{array}$ & $\begin{array}{c}-0.374 \\
(-0.681)\end{array}$ & $\begin{array}{l}-0.261 \\
(-0.416)\end{array}$ \\
\hline $\ln (\mathrm{VP}$ delta $)$ & & & & $\begin{array}{c}-0.093 \\
(-0.735)\end{array}$ & $\begin{array}{l}-0.151 \\
(-1.084)\end{array}$ \\
\hline $\ln (\mathrm{VP}$ vega $)$ & & & & $\begin{array}{c}0.046 \\
(-0.019)\end{array}$ & $\begin{array}{l}-0.002 \\
(-0.291)\end{array}$ \\
\hline $\ln$ (Equity pay ratio) & & & & $\begin{array}{c}0.320 \\
(1.357)\end{array}$ & $\begin{array}{c}0.326 \\
(1.238)\end{array}$ \\
\hline $\ln$ (Industry VP pay ratio) & & & & $\begin{array}{c}-0.205 \\
(-1.152)\end{array}$ & $\begin{array}{r}-0.257 \\
(-1.226)\end{array}$ \\
\hline VP pay rise after acquisition $(\%)$ & & & & $\begin{array}{c}0.016 \\
(0.084)\end{array}$ & $\begin{array}{c}0.167 \\
(0.758)\end{array}$ \\
\hline SD(VP ability) & & & & $\begin{array}{l}-0.263 \\
(-1.178)\end{array}$ & $\begin{array}{l}-0.191 \\
(-0.713)\end{array}$ \\
\hline Controls & Yes & Yes & Yes & Yes & Yes \\
\hline Constant & Yes & Yes & Yes & Yes & Yes \\
\hline Year fixed effects & Yes & Yes & Yes & Yes & Yes \\
\hline Industry fixed effects & Yes & Yes & Yes & Yes & Yes \\
\hline No. of observations & 8,911 & 8,911 & 6,476 & 3,985 & 2,822 \\
\hline$R^{2}$ & .04 & .04 & .05 & .06 & .08 \\
\hline
\end{tabular}

This table reports the summary of additional robustness test results for tournament incentives on acquisition performance. Table A1 in the appendix defines all variables. $t$-statistics are calculated from robust standard errors clustered by firm and are displayed in parentheses. ${ }^{*} p<.1 ;{ }^{*} p<.05 ; * * * p .01$.

We find that VPs sit on the boards of $71 \%$ of the firms. Column 5 of Table 11 shows the results. After the exclusion of firms with no VPs on the board, we find that a 1-standard-deviation increase in the pay ratio centered on its sample mean reduces CAR by 30 basis points. While the point estimate is higher than the estimate obtained using our full sample, the difference is not statistically significant.

\section{Conclusion}

In this paper, we examine the effects of tournament incentives of senior executives, created by an observable pay differential between the CEO and other senior executives, on the performance of corporate acquisitions. Using a large sample of corporate acquisitions made by U.S. firms over the period from 1994 to 2015, we show that stronger tournament incentives lead to worse acquisition performance. This relation holds in 
an instrumental variable regression analysis and in propensity-score matched sample regressions. Furthermore, our empirical evidence indicates that the negative effect of tournament incentives is driven by the risk-seeking behavior of senior executives.

We also address an alternative interpretation of our empirical findings. Some authors have argued that the pay ratio between the CEO and other senior executives also can be a measure of CEO entrenchment, and prior literature has found that entrenched CEOs make worse acquisitions. We explicitly control for CEO entrenchment in all of our regressions and also adopt a two-stage regression approach to distinguish our tournament hypothesis from the entrenchment hypothesis. We find that the negative relationship between tournament incentives and acquisition performance holds in the two-stage regression models, enabling us to rule out this alternative interpretation of our results.

Our paper contributes to the extant literature on corporate acquisitions by showing that senior executives play a crucial role in corporate acquisition decisions in addition to the CEO. Specifically, we show that tournament incentives induce senior executives to support overly risky acquisitions that, on average, destroy shareholder value. This channel of wealth destruction adds to our current knowledge on how acquiring shareholders lost significant wealth in the hands of corporate managers as documented by Moeller, Schlingemann, and Stulz (2005). Overall, our findings add to the debate on whether tournament incentives work to influence managerial decision-making by uncovering an understudied dark side of tournament incentives on corporate investment decisions within firms. Specifically, we present new empirical evidence to uncover that tournament incentives induces undesirable corporate acquisition decisions and outcomes for shareholder wealth. Our results provide corporate boards with another pivotal factor to consider when designing compensation structures that can effectively lift firm performance. We leave the investigation of how executive compensation and governance mechanisms should be designed to mitigate the adverse consequences of tournament incentives on corporate policies to future research. 


\section{Appendix}

Table A1

Variable definitions

Variable Definitions

Measures of CEO tournament

ln(Pay ratio) Natural logarithm of the ratio between CEO's total compensation

$\begin{array}{ll}\ln \text { (Pay gap) } & \text { (Execucomp: TDC1) and mean VP's total compensation } \\ \text { Natural logarithm of the difference between CEO's total compensation }\end{array}$

(Execucomp: TDC1) and median VP's total compensation

Measures of acquisition risk and performance

CAR $(-2,+2) \quad$ Acquirer's 5-day cumulative abnormal return calculated using the market model. The market model parameters are estimated over the period ($210,-11)$ with the CRSP value-weighted return as the market index

Deal risk Post-acquisition period (11 days to 70 days following the effective date) minus preacquisition period ( 120 days to 60 days prior to the an-

Bidder CEO and VP characteristics nouncement date) stock-return standard deviation

$\ln (\mathrm{CEO}$ delta)

$\ln (\mathrm{CEO}$ vega $)$

CEO-chair

CEO is highly tenured

CEO hubris

CEO entrenchment

CEO turnover

Number of VPs

VP acquisition experience

$\ln$ (VP delta)

$\ln (\mathrm{VP}$ vega $)$

$\ln$ (Equity pay ratio)

ln(Industry VP pay ratio)

VP pay rise after acquisition $(\%)$

VP ability
Natural logarithm of dollar increase in acquirer CEO's portfolio wealth for a percentage increase in the underlying stock price

Natural logarithm of dollar increase in acquirer CEO's portfolio wealth for a percentage increase in the standard deviation of the underlying stock price

Dummy variable that equals 1 if the CEO is also the Chair of the firm, and zero otherwise

Dummy variable that equals to one if CEO tenure falls in the fourth quartile, and zero otherwise

Dummy variable that equals one if the Demerjian, Lev, and McVay (2012) managerial ability index falls in the fourth quartile, and zero otherwise

CEO entrenchment index consisting of CEO/chair duality, whether the CEO is the only insider on the board, whether the CEO is highly tenured, CEO hubris and the entrenchment index A higher value indicates greater CEO entrenchment

Dummy variable that equals one for the year after a CEO turnover event, and zero otherwise

Number of VPs reported in Execucomp

Number of VPs within the firm who have worked in a firm that conducted an acquisition in the past 3 years

Natural logarithm of one plus the dollar increase in the average VP's portfolio wealth for a percentage increase in the underlying stock price Natural logarithm of one plus the dollar increase in the average VP's portfolio wealth for a percentage increase in the standard deviation of the underlying stock price

Natural logarithm of the ratio between the fraction of equity compensation of the CEO and the average fraction of equity compensation of VPs. Equity compensation is calculated as the sum of the value of stock grants and option grants

Natural logarithm of the ratio between average VP total compensation and average VP total compensation in the same industry and in the same size quartile as the firm

Ratio between the average VP total compensation in the year after the acquisition and the average VP total compensation in the year of the acquisition

VP ability index consisting of VP's education background and professional experience sourced from BoardEx. Education background contains information on whether a VP holds undergraduate, graduate, and/ or MBA degrees. Professional experience contains information on whether a VP has legal/consulting experience, academic experience, accounting/finance experience, and/or management experience. Higher value indicates higher VP ability 
Table A1

Continued

Variable Definitions

Bidder firm characteristics

$\ln$ (Firm size)

Leverage

Natural logarithm of net sales (SALE)

Tobin's q

Book value of debt (DLTT+DLC) divided by the book value of debt plus market value of equity (DLTT + DLC + CSHO*PRCC)

Cash flow Market value of assets over the book value of assets (AT - CEQ + CSHO*PRCC)/AT)

Board independence Operating income before depreciation (OIBDP) scaled by the book value of total assets (AT)

Board size Percentage of independent directors on the board (Source: Riskmetrics) Number of directors on the board (Source: Riskmetrics)

Institutional ownership

Entrenchment index

Firm governance

Percentage of the firm owned by institutional investors, sourced from $13 \mathrm{f}$ filings

Entrenchment index sourced from Bebchuk, Cohen, and Ferrell (2009)

Governance quality index consisting of board independence, board size and institutional ownership. Higher value indicates better firm governance

Stock price runup

Deal characteristics

Relative deal size

Bidder's buy and hold abnormal return (BHAR) during the period (-210, -11). The market index is the CRSP value-weighted return

Deal value (SDC: DEALVALUE) over bidder's market value of equity (CSHO*PRCC). Deal value is measured as the total value of consideration paid by the acquirer excluding fees and expenses

Cross-industry

Dummy variable that equals one if bidder and target do not share a

Fama-French 49 industry, and zero otherwise

Cross-border

Dummy variable that equals one if the target nation is not the same as acquirer nation, and zero otherwise

All-cash deal

Private target

Subsidiary target

M\&A wave

Other variables

Insider CEO

VP pay dispersion

Industry concentration

Product similarity

Local supply of VPs

Dummy variable that equals 1 for purely cash-financed deals, and zero otherwise

Dummy variable that equals 1 for public targets, and zero otherwise

Dummy variable that equals 1 for subsidiary targets, and zero otherwise

Number of acquisitions in a Fama-French 49 industry in a given year

Dummy variable that equals 1 if the CEO has worked for the firm prior to becoming the CEO, and zero otherwise

Standard deviation of VP pay

HHI index sourced from Hoberg and Phillips (2016)

Total similarity index sourced from Hoberg and Phillips (2016)

Sum of total number of VPs working in firms in the same ZIP code, same size quartile, and the same Fama-French 49 industry as the acquirer

$\ln$ (Size-adjusted industry Average of $\ln$ (Pay ratio) for firms in the same size quartile and the same pay ratio) Fama-French 49 industry as the acquirer

$\ln$ (Size-adjusted industry CEO delta)

Average of $\ln (C E O$ delta $)$ for firms in the same size quartile and the same Fama-French 49 industry as the acquirer

$\ln$ (Size-adjusted industry CEO delta) Average of $\ln (C E O$ vega $)$ for firms in the same size quartile and the same Fama-French 49 industry as the acquirer

This table describes the variables used in the paper. 
Table A2

Breakdown of number of acquisitions by each firm

Total acquisitions

Number of firms

\begin{tabular}{|c|c|}
\hline 1 & 513 \\
\hline 2 & 343 \\
\hline 3 & 224 \\
\hline 4 & 193 \\
\hline 5 & 151 \\
\hline 6 & 107 \\
\hline 7 & 83 \\
\hline 8 & 61 \\
\hline 9 & 41 \\
\hline 10 & 44 \\
\hline 11 & 27 \\
\hline 12 & 21 \\
\hline 13 & 24 \\
\hline 14 & 16 \\
\hline 15 & 10 \\
\hline 16 & 6 \\
\hline 17 & 10 \\
\hline 18 & 9 \\
\hline 19 & 11 \\
\hline 20 & 3 \\
\hline 21 & 6 \\
\hline 22 & 3 \\
\hline 23 & 4 \\
\hline 24 & 2 \\
\hline 26 & 4 \\
\hline 27 & 1 \\
\hline 29 & 2 \\
\hline 30 & 1 \\
\hline 31 & 2 \\
\hline 32 & 3 \\
\hline 33 & 3 \\
\hline 34 & 1 \\
\hline 37 & 1 \\
\hline 38 & 2 \\
\hline 41 & 1 \\
\hline 65 & 1 \\
\hline
\end{tabular}

This table provides the breakdown of the number of acquisitions conducted by each firm in our sample. 
Table A3

Baseline regression results using different level of standard error clustering

(1)

SE clustered by industry
(2)

SE clustered by industry-year

\begin{tabular}{|c|c|c|}
\hline $\ln$ (Pay ratio) & $\begin{array}{c}-0.354^{* *} \\
(-2.376)\end{array}$ & $\begin{array}{l}-0.354^{*} \\
(-1.889)\end{array}$ \\
\hline $\ln ($ CEO delta $)$ & $\begin{array}{c}0.144 * * \\
(2.095)\end{array}$ & $\begin{array}{l}0.144^{*} \\
(2.003)\end{array}$ \\
\hline $\ln (\mathrm{CEO}$ vega $)$ & $\begin{array}{l}-0.101^{*} \\
(-1.853)\end{array}$ & $\begin{array}{c}-0.101 \\
(-1.505)\end{array}$ \\
\hline CEO entrenchment & $\begin{array}{c}-0.177 \\
(-0.599)\end{array}$ & $\begin{array}{c}-0.177 \\
(-0.588)\end{array}$ \\
\hline CEO turnover & $\begin{array}{l}-0.476^{* *} \\
(-2.045)\end{array}$ & $\begin{array}{c}-0.476^{* *} \\
(-2.313)\end{array}$ \\
\hline Number of VPs & $\begin{array}{l}-0.069 \\
(-0.995)\end{array}$ & $\begin{array}{l}-0.069 \\
(-0.851)\end{array}$ \\
\hline VP acquisition experience & $\begin{array}{c}0.044 \\
(1.187)\end{array}$ & $\begin{array}{c}0.044 \\
(1.015)\end{array}$ \\
\hline $\ln$ (Sales) & $\begin{array}{l}-0.156^{* *} \\
(-2.449)\end{array}$ & $\begin{array}{l}-0.156^{* *} \\
(-2.182)\end{array}$ \\
\hline Leverage & $\begin{array}{c}0.869 \\
(1.593)\end{array}$ & $\begin{array}{c}0.869 \\
(1.465)\end{array}$ \\
\hline Tobin's q & $\begin{array}{l}-0.184 * * \\
(-2.193)\end{array}$ & $\begin{array}{l}-0.184^{*} \\
(-1.881)\end{array}$ \\
\hline Cash flow & $\begin{array}{c}1.873 \\
(1.511)\end{array}$ & $\begin{array}{c}1.873 \\
(1.122)\end{array}$ \\
\hline Firm governance & $\begin{array}{c}-0.054 \\
(-0.244)\end{array}$ & $\begin{array}{c}-0.054 \\
(-0.224)\end{array}$ \\
\hline Stock price runup & $\begin{array}{c}-1.132 * * * \\
(-5.385)\end{array}$ & $\begin{array}{c}-1.132^{* * *} * \\
(-6.216)\end{array}$ \\
\hline Relative deal size & $\begin{array}{c}0.417 \\
(0.826)\end{array}$ & $\begin{array}{c}0.417 \\
(0.592)\end{array}$ \\
\hline Cross-industry & $\begin{array}{c}-0.107 \\
(-0.738)\end{array}$ & $\begin{array}{c}-0.107 \\
(-0.817)\end{array}$ \\
\hline Cross-border & $\begin{array}{l}-0.126 \\
(-0.746)\end{array}$ & $\begin{array}{c}-0.126 \\
(-0.880)\end{array}$ \\
\hline All-cash deal & $\begin{array}{c}0.481 * * * \\
(3.508)\end{array}$ & $\begin{array}{c}0.481 * * * \\
(5.864)\end{array}$ \\
\hline Private target & $\begin{array}{c}1.318 * * * \\
(6.428)\end{array}$ & $\begin{array}{c}1.318 * * * \\
(5.744)\end{array}$ \\
\hline Subsidiary target & $\begin{array}{c}1.863 * * * \\
(8.671)\end{array}$ & $\begin{array}{c}1.863 * * * \\
(9.337)\end{array}$ \\
\hline M\&A wave & $\begin{array}{c}-0.036 \\
(-0.040)\end{array}$ & $\begin{array}{c}-0.036 \\
(-0.033)\end{array}$ \\
\hline Constant & $\begin{array}{c}2.045^{* *} \\
(2.010)\end{array}$ & $\begin{array}{l}2.045^{* *} \\
(2.334)\end{array}$ \\
\hline Year fixed effects & Yes & Yes \\
\hline Industry fixed effects & Yes & Yes \\
\hline No. of observations & 8,911 & 8,911 \\
\hline$R^{2}$ & .04 & .04 \\
\hline
\end{tabular}

This table reports the estimation results of tournament incentives on acquisition performance with different levels of standard error clustering. Table Al in the appendix defines all variables. $t$-statistics are displayed in parentheses. ${ }^{*} p<.1 ;{ }^{* *} p<.05 ;{ }^{* * *} p<.01$. 
Table A4

Deal risk analysis using within-industry deals only

Within industry deals only
(1)
(2)
(3)
Deal risk

(4)

\begin{tabular}{|c|c|c|c|c|}
\hline Dep. $=$ CAR & Q1 - Q3 & Q4 & Q1 - Q3 & Q4 \\
\hline \multirow[t]{3}{*}{$\ln$ (Pay ratio) } & -0.123 & $-2.016^{* * *}$ & $-0.471 * *$ & $-0.871 * *$ \\
\hline & $(-0.634)$ & $(-4.080)$ & $(-2.164)$ & $(-2.229)$ \\
\hline & \multicolumn{2}{|c|}{$\begin{array}{c}\mathrm{H} 0: \beta(1)=\beta(2) \\
(0.000)\end{array}$} & \multicolumn{2}{|c|}{$\begin{array}{c}\mathrm{H} 0: \beta(3)=\beta(4) \\
(0.354)\end{array}$} \\
\hline \multirow{2}{*}{$\ln (\mathrm{CEO}$ delta $)$} & 0.130 & $0.431 *$ & 0.128 & $0.389 * *$ \\
\hline & $(1.534)$ & $(1.681)$ & $(1.269)$ & $(2.043)$ \\
\hline \multirow[t]{2}{*}{$\ln (\mathrm{CEO}$ vega $)$} & -0.101 & -0.177 & -0.115 & -0.226 \\
\hline & $(-1.426)$ & $(-0.874)$ & $(-1.442)$ & $(-1.491)$ \\
\hline \multirow[t]{2}{*}{ CEO entrenchment } & 0.047 & -0.552 & -0.247 & 0.510 \\
\hline & $(0.128)$ & $(-0.560)$ & $(-0.618)$ & $(0.650)$ \\
\hline \multirow[t]{2}{*}{ CEO turnover } & -0.311 & $-2.071 * * *$ & $-0.643^{*}$ & $-1.212^{*}$ \\
\hline & $(-0.981)$ & $(-2.742)$ & $(-1.834)$ & $(-1.883)$ \\
\hline \multirow[t]{2}{*}{ Number of VPs } & -0.073 & -0.164 & -0.092 & -0.118 \\
\hline & $(-0.822)$ & $(-0.815)$ & $(-0.926)$ & $(-0.622)$ \\
\hline \multirow[t]{2}{*}{ VP experience } & 0.070 & -0.022 & 0.044 & -0.084 \\
\hline & $(1.382)$ & $(-0.177)$ & $(0.744)$ & $(-0.830)$ \\
\hline \multirow[t]{2}{*}{$\ln ($ Firm size $)$} & -0.112 & -0.325 & $-0.313 * * *$ & 0.065 \\
\hline & $(-1.328)$ & $(-1.470)$ & $(-3.515)$ & $(0.351)$ \\
\hline \multirow[t]{2}{*}{ Leverage } & 0.843 & 1.022 & $1.511^{*}$ & 0.911 \\
\hline & $(1.230)$ & $(0.681)$ & $(1.877)$ & $(0.644)$ \\
\hline \multirow[t]{2}{*}{ Tobin's q } & -0.001 & -0.131 & -0.069 & 0.046 \\
\hline & $(-0.006)$ & $(-0.408)$ & $(-0.569)$ & $(0.239)$ \\
\hline \multirow[t]{2}{*}{ Cash flow } & 1.435 & $6.704^{*}$ & 2.562 & 1.124 \\
\hline & $(0.891)$ & $(1.783)$ & $(1.373)$ & $(0.384)$ \\
\hline \multirow[t]{2}{*}{ Firm governance } & $-0.602^{* *}$ & 0.821 & -0.270 & -0.114 \\
\hline & $(-1.993)$ & $(1.152)$ & $(-0.833)$ & $(-0.180)$ \\
\hline \multirow[t]{2}{*}{ Stock price runup } & $-1.034 * * *$ & $-1.688^{* * *}$ & $-1.442 * * *$ & -0.593 \\
\hline & $(-3.601)$ & $(-2.871)$ & $(-4.812)$ & $(-1.028)$ \\
\hline \multirow[t]{2}{*}{ Relative deal size } & $6.731 * * *$ & 0.177 & 0.534 & 0.405 \\
\hline & $(2.643)$ & $(0.207)$ & $(0.793)$ & $(0.306)$ \\
\hline \multirow[t]{2}{*}{ Cross-border } & -0.221 & 0.895 & -0.233 & -0.100 \\
\hline & $(-0.973)$ & $(1.233)$ & $(-0.953)$ & $(-0.181)$ \\
\hline \multirow[t]{2}{*}{ All-cash deal } & 0.209 & $1.652 * * *$ & $0.568 * * *$ & 0.612 \\
\hline & $(1.126)$ & $(3.177)$ & $(2.718)$ & $(1.601)$ \\
\hline \multirow[t]{2}{*}{ Private target } & $0.726 * * *$ & $3.185 * * *$ & $1.422 * * *$ & $1.252 * *$ \\
\hline & $(2.766)$ & $(4.721)$ & $(4.880)$ & $(2.064)$ \\
\hline \multirow[t]{2}{*}{ Subsidiary target } & $1.132 * * *$ & $3.948 * * *$ & $2.041 * * *$ & $2.161 * * *$ \\
\hline & $(3.986)$ & $(6.521)$ & $(6.924)$ & (3.388) \\
\hline \multirow[t]{2}{*}{ M\&A wave } & -0.332 & -3.220 & 0.279 & -2.863 \\
\hline & $(-0.307)$ & $(-1.014)$ & $(0.221)$ & $(-1.367)$ \\
\hline \multirow[t]{2}{*}{ Constant } & -0.685 & 2.819 & -0.379 & 0.763 \\
\hline & $(-0.316)$ & $(0.980)$ & $(-0.163)$ & $(0.454)$ \\
\hline Year fixed effects & Yes & Yes & Yes & Yes \\
\hline Industry fixed effects & Yes & Yes & Yes & Yes \\
\hline No. of observations & 3,830 & 1,276 & 3,830 & 1,276 \\
\hline$R^{2}$ & .04 & .19 & .07 & .09 \\
\hline
\end{tabular}

This table reports the effect of tournament incentives on acquisition performance conditional upon deal risk using a sample of within-industry deals only. Deal size is measured as the relative deal size. Deal risk is measured as the post-acquisition minus preacquisition stock return standard deviations. Table A1 in the appendix defines all variables. $t$-statistics are calculated from robust standard errors clustered by firm and are displayed in parentheses. ${ }^{*} p<.1 ;{ }^{* *} p<.05 ;{ }^{* * *} p<.01$. 


\section{References}

Adams, R. B., H. Almeida, and D. Ferreira. 2005. Powerful CEOs and their impact on firm performance. Review of Financial Studies 18:1403-32.

Adams, R. B., B. E., Hermalin, and M. S. Weisbach. 2010. The role of boards of directors in corporate governance: A conceptual framework and survey. Journal of Economic Literature 48:58-107.

Aggarwal, R., I. Erel, M. Ferreira, and P. Matos. 2011. Does governance travel around the world? Evidence from institutional investors. Journal of Financial Economics 100:154-81.

Agrawal, A., and G. Mandelker. 1987. Managerial incentives and corporate investment and financing decisions. Journal of Finance 42:823-37.

Andrade, G., M. Mitchell, and E. Stafford. 2001. New evidence and perspectives on mergers. Journal of Economic Literature 15:103-20.

Armstrong, C. S, and R. Vashishtha. 2012. Executive stock options, differential risk-taking incentives, and firm value. Journal of Financial Economics 2012:70-88.

Bebchuk, L, M. Cremers, and U. Peyer. 2011. The CEO pay slice. Journal of Financial Economics 102:199-221.

Berger, P., E. Ofek, and D. Yermack. 1997. Managerial entrenchment and capital structure decisions. Journal of Finance 52:1411-38.

Bizjak, J. M., J. A. Brickley, and J. L. Coles. 1993. Stock-based incentive compensation and investment behaviour. Journal of Accounting and Economics 16:349-72.

Bognanno, M. L. 2001. Corporate tournaments. Journal of Labor Economics 19:290-315.

Burns, N., K. Minnick, and L. Starks. 2017. CEO tournaments: A cross-country analysis of causes, cultural influences and consequences. Journal of Financial and Quantitative Analysis 52:519-51.

Chen, J., M. Ezzamel, and Z. Cai. 2011. Managerial power theory, tournament theory, and executive pay in China. Journal of Corporate Finance 17:1176-99.

Chen, Z., Y. Huang, and K. Wei. 2013. Executive pay disparity and the cost of equity capital. Journal of Financial and Quantitative Analysis 48:849-85.

Coakley, J., and S. Iliopoulou. 2006. Bidder CEO and other executive compensation in UK M\&As. European Financial Management 12:609-31.

Coles, J. L., N. D. Daniel, and L. Naveen. 2006. Managerial incentives and risk-taking. Journal of Financial Economics 79:431-68.

Coles, J. L., M. L. Lemmon, and J. F. Meschke. 2012. Structural models and endogeneity in corporate finance: The link between managerial ownership and corporate performance. Journal of Financial Economics 103:149-68.

D’Onfro, J. 2015. Meet the man responsible for Google's billion-dollar acquisitions. Business Insider, May 3. https://www.businessinsider.com.au/don-harrison-google-corporate-development-acquisitions2015-5.

Datta, S., M. Iskandar-Datta, and K. Raman. 2001. Executive compensation and corporate acquisition decisions. Journal of Finance 56:2299-336.

Demerjian, P., B. Lev, and S. McVay. 2012. Quantifying managerial ability: A new measure and validity tests. Management Science 58:1229-48.

Edmans, A., X. Gabaix, and D. Jenter. 2017. Executive compensation: A survey of theory and evidence. Working Paper, London Business School.

Fang, D., T. Noe, and P. Strack. 2019. Turning up the heat: The demoralizing effect of competition in contests. Journal of Political Economy. Advance Access published July 26, 2019, 10.1086/705670. 
Fedaseyeu, V., J. S. Linck, and H. F. Wagner. 2018. Do qualifications matter? New evidence on board functions and director compensation. Journal of Corporate Finance 48:816-39.

Fee, C. E., C. J. Hadlock, J. Huang, and J. R. Pierce. 2018. Robust models of CEO turnover: New evidence on relative performance evaluation. Review of Corporate Finance Studies 7:70-100.

Firth, M. 1991. Corporate takeovers, stockholder returns and executive rewards. Managerial and Decision Economics 12:421-8.

Fuller, K., J. Netter, and M. Stegemoller. 2002. What do returns to acquiring firms tell us? Evidence from firms that make many acquisitions. Journal of Finance 57:1763-94.

Gilpatric, S. 2009. Risk taking in contests and the role of carrots and sticks. Economic Inquiry 47:266-77.

Goel, A. M., and A. V. Thakor. 2008. Overconfidence, CEO selection, and corporate governance. Journal of Finance 63:2737-84.

Gormley, T., and D. Matsa. 2014. Common errors: How to (and not to) control for unobserved heterogeneity. Review of Financial Studies 27:617-61.

Graebner, M. E. 2009. Caveat venditor: Trust asymmetries in acquisitions of entrepreneurial firms. Academy of Management Journal 52:435-72.

Greene, D., and J. Smith. 2018. When do CEOs delegate authority? Evidence from mergers and acquisitions. Working Paper, Clemson University.

Guo, L., and R. W. Masulis. 2015. Board structure and monitoring: New evidence from CEO turnovers. Review of Financial Studies 28:2770-811.

Haß, L. H., M. A. Müller, and S. Vergauwe. 2015. Tournament incentives and corporate fraud. Journal of Corporate Finance 34:251-67.

Hackbarth, D., and E. Morellec. 2008. Stock returns in mergers and acquisitions. Journal of Finance 63:1213-52.

Harford, J. 1999. Corporate cash reserves and acquisitions. Journal of Finance 54:1969-97.

Harford, J., M. Humphery-Jenner, and R. Powell. 2012. The sources of value destruction in acquisitions by entrenched managers. Journal of Financial Economics 106:247-61.

Hjertstrand, P., and J.L. Swfford, 2019. Revealed preference tests of indirect and homothetic weak separability of financial assets, consumption and leisure. Journal of Financial Stability, 42:108-114.

Hoberg, G., and G. Phillips. 2016. Text-based network industries and endogenous product differentiation. Journal of Political Economy 124:1423-65.

Huang, Q., F. Jiang, E. Lie, and K. Yang. 2014. The role of investment banker in M\&A. Journal of Financial Economics 112:269-86.

Hvide, H. K. 2002. Tournament rewards and risk taking. Journal of Labor Economics 20:877-98.

Jensen, M. 1986. Agency costs of free cash flow, corporate finance, and takeovers. American Economic Review 76:323-9.

1993. The modern industrial revolution, exit, and failure of internal control systems. Journal of Finance 48:35-44.

Jenter, D., and D. Lewellen. 2015. CEO preferences and acquisitions. Journal of Finance 70:2813-52.

Jia, N., X. Tian, and W. Zhang. 2017. The real effects of tournament incentives: The case of firm innovation. Research Paper, Kelley School of Business.

Jiang, W. 2017. Have instrumental variables brought us closer to the truth. Review of Corporate Finance Studies 6:127-40. 
Kale, J. R., E. Reis, and A. Venkateswaran. 2009. Rank-order tournaments and incentive alignment: The effect on firm performance. Journal of Finance 64:1479-512.

Kini, O., and R. Williams. 2012. Tournament incentives, firm risk, and corporate policies. Journal of Financial Economics 103:350-76.

Knyazeva, A., D. Knyazeva, and R. W. Masulis. 2013. The supply of corporate directors and board independence. Review of Financial Studies 26:1561-605.

Kumar, P., and N. Langberg. 2014. Optimal incentive contracts and information cascades. Review of Corporate Finance Studies 3:123-61.

Lang, L. H. P., R. M. Stulz, and R. A. Walkling. 1991. A test of the free cash flow hypothesis: The case of bidder returns. Journal of Financial Economics 29:315-36.

Larcker, D., and B. Tayan. 2011. Leadership challenges at Hewlett Packard: Through the looking glass. Report, Stanford University.

Lazear, E. P., and S. Rosen. 1981. Rank-order tournaments as optimum labor contracts. Journal of Political Economics 89:841-64.

Lee, J., H. Shin, and H. Yun. 2018. Family feud: Succession tournaments and risk-taking in family firms. Working Paper, Warrington College of Business, University of Florida.

Lehn, K., and M. Zhao. 2006. CEO turnover after acquisitions. Are bad bidders fired? Journal of Finance 61:1759-811.

Lewellen, W., C. Loderer, and A. Rosenfeld. 1985. Merger decisions and executive stock ownership in acquiring firms. Journal of Accounting and Economics 7:209-31.

Masulis, R. W., C. Wang, and F. Xie. 2007. Corporate governance and acquirer returns. Journal of Finance 62:1851-89.

Masulis, R. W., and S. Zhang. 2018. What drives executive compensation gaps, tournament theory or managerial power? Working Paper, UNSW Business School.

Minnick, K., H. Unal, and L. Yang. 2011. Pay for performance? CEO compensation and acquirer returns in BHCs. Review of Financial Studies 24:439-72.

Moeller, S., F. Schlingemann, and R. Stulz. 2004. Firm size and the gains from acquisitions. Journal of Financial Economics 73:201-28.

2005. Wealth destruction on a massive scale? A study of acquiring-firm returns in the recent merger wave. Journal of Finance 60:757-82.

Murphy, K. J. 1999. Executive compensation. In Handbook of labor economics, eds. A. Orley and D. Card. Amsterdam, the Netherlands: Elsevier Science.

Myers, S. C., and N. S. Majluf. 1984. Corporate financing and investment decisions when firms have information that investors do not have. Journal of Financial Economics 13:187-221.

Petersen, M. A. 2009. Estimating standard errors in finance panel data sets: Comparing approaches. Review of Financial Studies 22:435-80.

Roll, R. 1986. The hubris hypothesis of corporate takeovers. Journal of Business 59:197-216.

Shen, C. H., and H. Zhang. 2018. Tournament incentives and firm innovation. Review of Finance 22:1515-48.

Yim, S. 2013. The acquisitiveness of youth: CEO age and acquisition behavior. Journal of Financial Economics 108:250-73. 